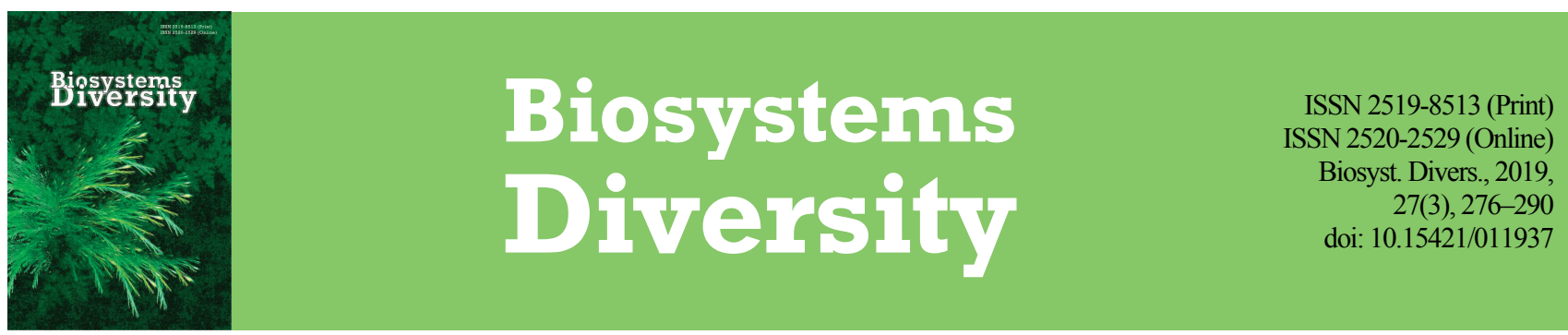

\title{
The non-native woody species of the flora of Ukraine: Introduction, naturalization and invasion
}

\author{
R. I. Burda, S. N. Koniakin \\ Institute for Evolutionary Ecology, National Academy of Sciences of Ukraine, Kyiv, Ukraine
}

Article info

Received 16.07.2019

Received in revised form 14.08.2019

Accepted 15.08.2019

Institute for Evolutionary Ecology, National Academy of Sciences of Ukraine,

Lebedeva st., 37,

Kyiv, 03143, Ukrain

Tel.: +38-097-245-99-18

E-mail: riburda@ukr.net, ser681@ukr.net

\section{Burda, R. I., \& Koniakin, S. N. (2019). The non-native woody species of the flora of Ukraine: Introduction, naturalization and invasion. Biosystems Diversity, 27(3), 276-290. doi:10.15421/011937}

The process of invasion, naturalization, dispersion and invasive activity of non-native woody species in 5 regional floras, 5 urban floras and over 30 floras of the protected areas is discussed. It has been established that 182 non-native species out of 95 genera and 45 families are currently at different naturalization stages in the spontaneous flora of Ukraine. In terms of life-forms, they may be divided as follows: trees $-41 \%$, shrubs $-35 \%$, trees $/$ shrubs $-15 \%$, lianas $-9 \%$. Most species spread both via seed dispersal and the vegetative way $-56 \%$, using only seed dispersal $-42 \%$, only the vegetative way $-2 \%$. According to the preliminary rating of species-wise invasive activity, 71 species ( $40 \%$ ) have naturalized completely, among them 20 invasive species, including 12 transformer species, 29 potentially invasive species, and 22 naturalized species which demonstrate no invasive tendencies. The initial stages of invasion of 111 species are as follows: introduction $-9 \%$, survival - $36 \%$, adaptation of the reproductive sphere $-28 \%$, establishment, formative of local populations $-27 \%$. In terms of dispersion, non-naturalized species are divided as follows: rare $-45 \%$, local $-16 \%$, sporadic $-6 \%$, unique $-12 \%$, spreading under control beyond collections and expositions in botanical gardens and arboretums $-21 \%$. Twelve transformer species, the greatest threat to local diversity, are Acer negundo, Ailanthus altissima, Amorpha fruticosa, Bupleurum fruticosum, Elaeagnus angustifolia, E. rhamnoides, Fraxinus ornus, Parthenocissus quinquefolia, P. vitacea, Robinia pseudoacacia, Rhamnus alaternus, Salix $\times$ blanda and 8 invasive proper species: Berberis aquifolia, Colutea orientalis, Daphne laureola, Prunus cerasifera, P. serotina, Quercus ilex, Viburnum tinus, Vitis vinifera. The list of alien species, most widespread in 50 regions of Europe, includes Robinia pseudoacacia (42 regions), Ailanthus altissima (40), Acer negundo (38), Prunus cerasus (34), Quercus rubra (34), Rosa rugosa (34), Prunus domestica (31). The mitigation of the impacts of these species on local biodiversity is possible via the restoration of local native plant communities, land use organization, strict selection of introduced species prior to the introduction, culture of planting management, preventive measures and extending awareness and sharing of information about plant invasions. Therefore, Ukraine's spontaneous flora is notable for the active process of naturalization of non-native woody species with considerable involvement of invasive alien species. This is the first and preliminary evaluation of the invasive activity of woody species in Ukraine's flora. The manifestations of the global tendency of increased involvement and invasive activity of alien woody species in domestic flora have been confirmed. These conclusions are also relevant for elaborating the system of preventive, containing and mitigating measures regarding plant invasions in Ukraine.

Keywords: invasive alien species; tree; shrub; liana; species invasive activity.

\section{Introduction}

It is hard to overestimate the role of woody plants in creating plant cover and nutrient cycling, transfer of energy and information in the biosphere. They are dominants of plant community complexes and nuclei of consortia in ecosystems. While improving the environment, humans have long tried to draw woody plants nearer, to use all their diversity in order to satisfy intellectual, aesthetic, recreational and utilitarian needs. Since the end of the 18th century, Ukraine has had the oldest introduction centers arboretums "Alexandria" and "Sofiivka", and somewhat younger collections of world flora treasures - the Nikitsky Botanical Garden, the arboretum of the biosphere reserve "Askania Nova", academic and university botanical gardens. In addition to their decorative, educational, aesthetic value and favourable impact on the environment, the establishment of the reserves of alien woody species (so called exotic plants) is relevant for greenery building, forestries and protective forestation, etc. However, the accumulation of exotic plants in cultivation is a remote risk of further invasions, naturalization, some of them penetrate to natural plant communities, which causes changes in the composition, structure and functions of the latter and poses a threat to the local gene fund.

Information on the distribution of alien plant species in the world is dramatic. The Global Naturalized Alien Flora (GloNAF) database contains 13,168 species or $3.9 \%$ of the extant global flora of vascular plants. These alien species have secondary regions (van Kleunen et al., 2015; Pyšek et al., 2017a, b). At least 75\% and $93 \%$ of the world's naturalized alien flora is grown in home and botanical gardens, respectively (van Kleunen et al., 2018). The role of evolutionary changes during biological invasions must be understood (Blackburn et al., 2014; Zenni et al., 2017). This is important for mitigating the impacts and threats of penetration of woody plants into the natural flora (Pollegioni et al., 2013; Hirsch et al., 2017; Gaskin et al., 2017).

The article starts the analysis of diversity of the woody species, introduced to Ukraine, in order to find those which have invaded native or native-related plant communities, formed stable self-restoring local populations in them, become naturalized, revealed the ability to invade, formed secondary ranges and their own ecological niches, become invasive; it aims to determine the level of invasive activity of alien woody species and cryptic (hidden) threats of non-native woody species at the initial stages of migration.

\section{Materials and methods}

Let us define the main terms used in this article. Non-native (adventive, non-indigenous, exotic) species are the species whose occurrence in a specific territory is not related to the processes of natural florogenesis. These have overcome the geographical barrier due to human activity. Among them, we 
distinguish alien species - completely naturalized, which created secondary ranges, and non-naturalized species, which are undergoing the first stages of migration. Spontaneous species are those, the occurrence and distribution of which in a specific territory does not depend on humans.

There is no separate accessible database in Ukraine, related to a relevant group of vascular plants in human life - woody species, intentionally introduced into the culture. In order to form the total list and the volume of cultivated woody species, we have had to review current "Catalogues" of collection funds of the botanical gardens (Kondratyuk, 1988; Kokhno, 1997; Grevtsova, 2000; Solomakha, 2007; Kolisnychenko et al., 2011) and arboretums (Kosenko, 2000). We also used some articles about live botanical collections and spontaneous dispersion of woody exotic species from collections and expositions within introduction centers. The invasive activity of alien species in Ukraine's spontaneous flora was studied beyond introduction centers in native and approximately native community complexes within protected areas (Baranovski et al., 2016; Lykholat et al., 2017, 2018a, 2018b). Special attention was paid to studying urban floras. We also noted the results of evaluating the invasive activity in regional floras, floras of agrolandscapes and floras of the nature reserve fund of different zones (Burda, $2003,2007,2018$ ). Only non-native and spontaneously spreading species of Ukraine's flora have been considered. Sometimes native species, specified in the mentioned articles, have not been included in the analyzed lists (Acer platanoides L., A. tataricum L., Sambucus nigra L. and Staphylea pinnata L.).

Non-native woody species, found in Ukraine's flora, have been characterized by 6 categories, traditional for invasive botany. The degree of their invasive activity has been described in accordance to the categories, implemented by the European Botanical Gardens Consortium (Mayorov et al., 2013). These are three categories of alien species: transformer species - a group of species, changing the conditions and nature of ecosystems in their larger area, they pose a threat to environmental safety of the region; invasive species - naturalized species, capable of having great amounts of progeny, due to which they spread rapidly across large distances from their paternal plants, are capable of invading and persisting in large areas, have invaded local community complexes, they affect local species, their communities and ecosystems; potentially invasive species - also naturalized species, which may become invasive upon future increase in their number, they do not have any visible impacts on local diversity; species, which have become naturalized, but have not demonstrated invasive activity. Additional consideration has been given to non-naturalized species in the process of naturalization, which are sometimes restored via seed dispersal or in a vegetative way near the area of native species, but are not capable of further invasion yet (a small number of diaspores, no functional connections). These plants do not demonstrate expressed tendencies of naturalization, their presence depends on constant stable input of diaspores from cultivated plants, though they do reproduce in some cases.

The species of the abovementioned groups are characterized in accordance to traditional classifications, used by Ukrainian authors in the abovementioned articles, which requires some elaboration (Didukh et al., 2000). The category "degree of naturalization" has 6 descriptors: agriophyte - naturalized species which invaded native and native-related habitats; hemiagriophyte - species naturalized mostly in habitats which are close to native or degraded ones; epoecophyte - species naturalized only in anthropogenically transformed habitats; ergasiophyte - species intentionally introduced by humans which sometimes escape the cultivation limits, but are usually in the immediate proximity to the place of cultivation; colonophyte, non-naturalized species, unstable element of flora, related to cultivation, somewhat adjusted to new conditions of survival, capable of periodic formation of seeds or reproduction in the vegetative way; ephemerophyte - also non-naturalized species, unstable element of flora, which periodically occur in the places of cultivation of introduced woody species or among secondary habitats and vanish with time, as they are accidental migrants. The following species categories are distinguished in terms of occurrence: common species, widely and abundantly spread in the whole territory; local species, known in the whole territory, but abundant only in some locations; sporadic species, which occur frequently, but with low abundance, rare species, which are present in 3-5 (7) locations, unique species, found in 1-2 locations, and controlled species, spread via seed dispersal or in the vegetative way beyond collections and expositions within the botanical gardens and arboretums. Three categories have been distinguished in terms of lifeforms: a tree - a perennial woody plant with one well-formed stem and a crown, formed by side branches; a shrub - a perennial woody plant with multiple stems coming out of one source, the habitus does not have one well-formed main stem, and a liana - a perennial woody plant with a long stem, not capable of maintaining the vertical position without any additional support.

The names of the species are presented according to "The Plant List" database. The authors of all the names of the species, mentioned in the text, are given in Tables 5 and 6. The volumes of families of Magnoliophyta (Angiosperms) and the sequence of their location in Tables 2, 5 and 6 are in accordance to "Synopsis of Families and Orders of Angiosperms of the Flora of Ukraine" (Mosyakin, 2013).

\section{The non-native woody species of the flora of Ukraine, escaping from cultivation in botanical gardens and arboretums}

Over 50 centers of plant introduction are officially registered in Ukraine (Cherevchenko, 2011), and 10 of them are over 130 years old (Table 1). In addition, there are private commercial centers which import decorative plants, including trees, shrubs, and lianas, for sale. The attempts at finding and summarizing the diversity of live collections of the botanical gardens and arboretums have failed due to the absence of any unified database in free access mode. Our centers of plant introduction are mainly located in the temperate zone. They have been working for many years within creative cooperation of the Council of Botanical Gardens and Arboretums of Ukraine, exchanging their methods and seeds.

Taking into consideration these two circumstances, it becomes clear that the collections of woody plants in the introduction centers are somewhat duplicated. It would be reasonable to consider the richest collections of woody plants, collected in the arboretum "Sofiivka", the M. M. Hryshko National Botanical Garden, the O. V. Fomin Botanical Garden, and the arboretum of the Nititsky Botanical Garden, which is located in conditions, approximated to those of the eastern Mediterranean (Table 1).

However, it is common knowledge that "every garden is famous for its own collections". For instance, the National Arboretum "Sofiiv$\mathrm{ka}$ " is known for its rich collections of the genera Corylus -28 species, Fagus-21, Picea - 41, 100 species of lianas and over 320 varieties of roses (Kosenko, 2000). The O. V. Fomin Botanical Garden collected the most abundant generic complexes of Juniperus, Pinus, Cotoneaster, Forsythia, Lonicera, Magnolia, Rhododendron, Spiraea (Solomakha, 2007) and the Nikitsky Botanical Garden owns luxurient collections of genera Cupressus, Berberis, Cotoneaster, Lonicera, Philadelphus, Quercus, Spiraea, Thuja and Viburnum (Plugatar et al., 2015). As this statement reflects reality, it is noteworthy that the volume of the collections has neither changed much nor decreased for many years. For instance, the statistics for the arboretum of the Nikitsky Botanical Garden as of 1970 stated the presence of 1,704 species, including 689 trees, 879 shrubs, 136 lianas (Kormilitsin \& Golubeva, 1970). In 1971 the collection of the National Botanical Garden contained 2,054 species, including Angiospermae - 1,884 species and Gymnopsermae - 170 species (Rubtsov \& Gordienko, 1971). The collections, exceeding 1,000 woody species, have been collected in each of 8 introduction centers. It was recorded that in 1994 there were 1,655 species, 32 varieties, 547 forms of introduced trees, shrubs, and lianas (Kokhno, 1994). It should be also noted that the ratio between trees and shrubs (different life-forms) is not significant. It may be balanced (arboretum "Alexandria", the Botanical Garden of the National University of Dnipro, the Donetsk Botanical Gardens), or the number of species whose life-form is a shrub may exceed the number of species belonging to the tree life-form (arboretum "Sofiivka", the Kryvyi Rih Botanical Garden), or the ratio between the species with these life-forms is reverse (the Botanical Garden of Odesa University). Thus, the volumes of the richest modern collections and their age permit the assumption that these collections may be a source of dispersing non-native woody species into the domestic flora, completely established quite a long time ago. 
Table 1

The collection funds of woody plants in the leading Ukrainian centers of plant introduction

\begin{tabular}{|c|c|c|c|c|c|c|}
\hline \multirow{2}{*}{ Center of plant introduction } & \multirow{2}{*}{$\begin{array}{c}\text { Year of } \\
\text { foundation }\end{array}$} & \multirow{2}{*}{ Source } & \multicolumn{4}{|c|}{ Number of species } \\
\hline & & & total & tree* & shrub* & liana* \\
\hline The arboretum "Alexandria", NAS of Ukraine & 1793 & Galkin et al., 2017 & 1282 & 538 & 680 & 64 \\
\hline The National Arboretum "Sofiivka", NAS of Ukraine & 1796 & Kosenko, 2000 & 2400 & 800 & 160 & \\
\hline Botanical Garden of V. N. Karazin Kharkiv National University & 1804 & Alokhin et al., 2019 & 781 & - & - & - \\
\hline The Nikitsky Botanical Garden & 1812 & Plugatar et al., 2015 & 1690 & - & - & - \\
\hline The arboretum "Trostyanets", NAS of Ukraine & 1834 & Medvedyev \& Ilyenko, 2018 & 623 & - & - & - \\
\hline $\begin{array}{l}\text { O. V. Fomin Botanical Garden of Taras Shevchenko National Universi- } \\
\text { ty of Kyiv }\end{array}$ & 1839 & Solomakha, 2007 & 1828 & 923 & - & - \\
\hline Botanical Garden of Ivan Franko L'viv National University & 1852 & Prokopiv, 2004 & 787 & - & - & - \\
\hline Botanical Garden of Odesa of I. I. Mechnikov National University & 1867 & Filatova et al., 2014; Slyusarenko et al., 2017 & 1025 & 611 & 341 & 73 \\
\hline Botanical Garden of Yuriy Fedkovych Chernivtsi National University & 1877 & Cherevchenko, 2011 & 1150 & - & - & - \\
\hline $\begin{array}{l}\text { The arboretum of F. J. E. Falz-Fein "Askania Nova" Nature Biosphere } \\
\text { Reserve, NAAS of Ukraine }\end{array}$ & 1887 & Rubtsov et al., 2012 & 1114 & - & - & - \\
\hline $\begin{array}{l}\text { Botanical Garden of National University of Life and Environmental } \\
\text { Sciences of Ukraine, Kyiv }\end{array}$ & 1928 & Kolisnychenko et al., 2011 & 604 & - & - & - \\
\hline Botanical Garden of Oles Honchar Dnipro National University & 1933 & Kvasha et al., 2010 & 389 & 159 & 147 & 83 \\
\hline M. M. Hryshko National Botanical Garden, NAS of Ukraine & 1935 & Kokhno, 1997 & 1025 & - & - & - \\
\hline The Donetsk Botanical Garden, NAS of Ukraine & 1964 & Kondratyuk, 1988 & 868 & 457 & 411 & - \\
\hline The Kryvyi Rih Botanical Garden, NAS of Ukraine & 1980 & Grevtsova, 2000 & 661 & 245 & 393 & 23 \\
\hline
\end{tabular}

Note: "-"-marks: data is absent in source.

Only two published "Catalogues" of collection funds present systematized information about spontaneous dispersion of woody species from collections and expositions (Kondratyuk, 1988; Solomakha, 2007) (Table 2). Some fragments of the data are stated in special publications. After twenty years of introductory testing, 15 woody species, including 8 non-native cultivated ones, had natural regrowth in the Donetsk Botanical Garden of NAS of Ukraine (Kondratyuk, 1988). After 10 years, 54 species, including 13 aboriginal species, were found to be spontaneously distributing; 48 species had stable natural regrowth (Burda et al., 1998). It was noted that the species of genus Clematis, in particular, C. vitalba, spread far from the place of initial introduction, while remaining in the garden. Later it was additionally reported that 19 non-native species had spontaneously spread within the boundaries of the garden (Eremenko \& Ostapko, 2011, 2014). The total number amounted to 67 species. The location of $C$. vitalba was found $4 \mathrm{~km}$ from the garden and was interpreted as "escaping" from its collections (Ostapko et al., 2013). We place this assumption in question as C. vitalba was found on the roadside between the cities of Donetsk and Makiivka, which bordered summer cottages.

Table 2

The list of non-native species, spontaneously distributing in the centers of plant introduction

\begin{tabular}{|c|c|c|c|c|}
\hline Family & Taxon* & Life-form & Spread & Center of introduction \\
\hline \multicolumn{5}{|c|}{ Pinophyta } \\
\hline Pinaceae & *Larix decidua Mill. & tree & seed & Donetsk Botanical Garden \\
\hline Cupressaceae & *Thuja occidentalis L. & tree/shrub & seed & Botanical Garden of Ivan Franko National University of L'viv \\
\hline \multicolumn{5}{|c|}{ Magnoliophyta } \\
\hline Berberidaceae & Berberis aquifolium Pursh. & shrub & seed, vegetative way & Donetsk Botanical Garden \\
\hline Berberidaceae & *B. thunbergii DC. & shrub & seed, vegetative way & Arboretum "Alexandria" \\
\hline Berberidaceae & B. vulgaris L. & shrub & seed, vegetative way & Donetsk Botanical Garden \\
\hline Ranunculaceae & *Clematis gouriana Roxb. ex DC. & liana & seed, vegetative way & Donetsk Botanical Garden \\
\hline Ranunculaceae & ${ }^{*}$ C. jackmanii T. Moore. & liana & seed, vegetative way & Donetsk Botanical Garden \\
\hline Ranunculaceae & ${ }^{*}$ C. ligusticifolia $\mathrm{Nutt}$ & liana & seed, vegetative way & Donetsk Botanical Garden \\
\hline Ranunculaceae & *C. tangutica (Maxim.) Korsh. & liana & seed, vegetative way & Donetsk Botanical Garden \\
\hline Ranunculaceae & C. vitalba $\mathrm{L}$. & liana & seed, vegetative way & Arboretum "Alexandria", Donetsk Botanical Garden \\
\hline Ranunculaceae & *C. viticella $\mathrm{L}$. & liana & seed, vegetative way & Arboretum "Alexandria" \\
\hline Hamamelidaceae & $\begin{array}{l}\text { *Parrotia subaequalis (Hung T. Chang) } \\
\text { R. M. Hao \& H. T. Wei }\end{array}$ & tree/shrub & seed & M. M. Hryshko National Botanical Garden \\
\hline Grossulariaceae & *Ribes americanum Mill. & shrub & seed & Donetsk Botanical Garden \\
\hline Grossulariaceae & R. aureum Pursh & shrub & seed & Donetsk Botanical Garden \\
\hline Grossulariaceae & R. europaea (L.) Mill. & shrub & seed & Donetsk Botanical Garden \\
\hline Grossulariaceae & R. rubrum L. & shrub & seed & Donetsk Botanical Garden \\
\hline Grossulariaceae & R. spicatum Robson & shrub & seed & Donetsk Botanical Garden \\
\hline Vitaceae & *Ampelopsis aconitifolia Bunge & liana & seed, vegetative way & Donetsk Botanical Garden \\
\hline Vitaceae & $\begin{array}{l}\text { *A. delavayana var. glabra (Diels \& Gilg) } \\
\text { C. L. Li }\end{array}$ & liana & seed, vegetative way & Donetsk Botanical Garden \\
\hline Vitaceae & *A. bodinieri (H. Lév. \& Vaniot) Rehder & liana & seed, vegetative way & Donetsk Botanical Garden \\
\hline Vitaceae & $\begin{array}{l}\text { *A. glandulosa var. brevipedunculata (Max- } \\
\text { im.) Momiy }\end{array}$ & liana & seed, vegetative way & Donetsk Botanical Garden \\
\hline Vitaceae & Parthenocissus quinquefolia (L.) Planch. & liana & seed, vegetative way & $\begin{array}{l}\text { Botanical Garden of Oles Honchar National University of Dni- } \\
\text { pro, Donetsk Botanical Garden, O. V. Fomin Botanical Garden }\end{array}$ \\
\hline Vitaceae & P. vitacea (Knerr) Hitchc. & liana & seed, vegetative way & Donetsk Botanical Garden \\
\hline Vitaceae & *Vitis coignetiae Bull. ex Planch & liana & seed, vegetative way & Donetsk Botanical Garden \\
\hline Vitaceae & $V$. vinifera $\mathrm{L}$. & liana & seed, vegetative way & Donetsk Botanical Garden, O. V. Fomin Botanical Garden \\
\hline Fabaceae & Amorpha fruticosa $\mathrm{L}$. & shrub & seed, vegetative way & $\begin{array}{l}\text { Arboretum "Alexandria", Botanical Garden of Oles Honchar } \\
\text { National University of Dnipro, Donetsk Botanical Garden }\end{array}$ \\
\hline Fabaceae & Caragana arborescens Lam. & shrub & seed, vegetative way & Arboretum "Alexandria", Donetsk Botanical Garden \\
\hline Fabaceae & Gleditsia triacanthos $\mathrm{L}$. & tree & seed & $\begin{array}{l}\text { Botanical Garden of Oles Honchar National University } \\
\text { of Dnipro, Donetsk Botanical Garden }\end{array}$ \\
\hline Fabaceae & Gymnocladus dioica (L.) K. Koch & tree & seed & Arboretum "Alexandria", Donetsk Botanical Garden \\
\hline
\end{tabular}




\begin{tabular}{|c|c|c|c|c|}
\hline Family & Taxon* & Life-form & Spread & Center of introduction \\
\hline Fabaceae & Halimodendron halodendron (Pall.) Voss & shrub & seed & Donetsk Botanical Garden \\
\hline Fabaceae & Robinia pseudoacacia L. & tree & seed, vegetative way & $\begin{array}{l}\text { Arboretum "Alexandria", Donetsk Botanical Garden, } \\
\text { O. V. Fomin Botanical Garden, Botanical Garden } \\
\text { of Ivan Franko National University of L'viv }\end{array}$ \\
\hline Fabaceae & R. viscosa Vent. & tree & seed, vegetative way & Arboretum "Alexandria" \\
\hline Rosaceae & $\begin{array}{l}\text { Cerasus tomentosa (Thunb.) Wall. } \\
\text { ex T. T. Yu \& C. L. Li }\end{array}$ & shrub & seed & Donetsk Botanical Garden \\
\hline Rosaceae & Crataegus submollis Sarg. & shrub & seed & Arboretum "Alexandria" \\
\hline Rosaceae & Crataegus sp. & shrub & seed & Donetsk Botanical Garden \\
\hline Rosaceae & Malus domestica Borkh. & tree & seed, vegetative way & Donetsk Botanical Garden \\
\hline Rosaceae & Mespilus germanica L. & shrub & seed, vegetative way & Donetsk Botanical Garden \\
\hline Rosaceae & Physocarpus opulifolius (L.) Maxim. & shrub & seed, vegetative way & Arboretum "Alexandria" \\
\hline Rosaceae & Prunus armeniaca $\mathrm{L}$. & tree & seed, vegetative way & Donetsk Botanical Garden \\
\hline Rosaceae & P. cerasus $\mathrm{L}$. & tree & seed, vegetative way & Donetsk Botanical Garden \\
\hline Rosaceae & P. cerasifera Ehrh. & tree/shrub & seed, vegetative way & Arboretum "Alexandria" \\
\hline Rosaceae & P. mahaleb L. & shrub & seed & Donetsk Botanical Garden \\
\hline Rosaceae & P. serotina Ehrh. & tree/shrub & seed, vegetative way & Donetsk Botanical Garden \\
\hline Rosaceae & Rosa sp. & shrub & seed, vegetative way & Donetsk Botanical Garden \\
\hline Rosaceae & *Rubus odoratus L. & shrub & seed, vegetative way & Arboretum "Alexandria" \\
\hline Rosaceae & Sorbaria sorbifolia (L.) A. Braun & shrub & seed, vegetative way & $\begin{array}{c}\text { Arboretum "Alexandria", Donetsk Botanical Garden, } \\
\text { O. V. Fomin Botanical Garden }\end{array}$ \\
\hline Rosaceae & Spiraea $\times$ billardii Hérin & shrub & seed, vegetative way & Donetsk Botanical Garden \\
\hline Rosaceae & S. chamaedryfolia $\mathrm{L}$. & shrub & seed, vegetative way & Arboretum "Alexandria" \\
\hline Rosaceae & S. salicifolia $\mathrm{L}$. & shrub & seed, vegetative way & Arboretum "Alexandria" \\
\hline Elaeagnaceae & Elaeagnus angustifolia $\mathrm{L}$. & tree/shrub & seed, vegetative way & Donetsk Botanical Garden \\
\hline Elaeagnaceae & E. rhamnoides (L.) A. Nelson & shrub & seed, vegetative way & Donetsk Botanical Garden \\
\hline Elaeagnaceae & E. umbellata Thunb. & tree & seed, vegetative way & Arboretum "Alexandria" \\
\hline Ulmaceae & Celtis australis L. & tree & seed & M. M. Hryshko National Botanical Garden \\
\hline Ulmaceae & C. occidentalis L. & tree & seed & Donetsk Botanical Garden \\
\hline Ulmaceae & Ulmus pumila L. & tree & seed, vegetative way & Donetsk Botanical Garden, O. V. Fomin Botanical Garden \\
\hline Moraceae & Morus alba $\mathrm{L}$. & tree & seed & Donetsk Botanical Garden \\
\hline Fagaceae & Quercus rubra L. & tree & seed & $\begin{array}{c}\text { Arboretum "Alexandria", Donetsk Botanical Garden, } \\
\text { O. V. Fomin Botanical Garden }\end{array}$ \\
\hline Fagaceae & *Q. macranthera Fisch. \& C.A. Mey. ex Hohen. & tree & seed & M. M. Hryshko National Botanical Garden \\
\hline Juglandaceae & Juglans mandshurica Maxim. & tree & seed & Donetsk Botanical Garden \\
\hline Juglandaceae & J. nigra $\mathrm{L}$. & tree & seed & Arboretum "Alexandria" \\
\hline Juglandaceae & J. regia L. & tree & seed & $\begin{array}{c}\text { Arboretum "Alexandria", Donetsk Botanical Garden, } \\
\text { O. V. Fomin Botanical Garden }\end{array}$ \\
\hline Celastraceae & Celastrus angulata Maxim. & liana & seed, vegetative way & Donetsk Botanical Garden \\
\hline Celastraceae & C. flagellaris Rupr. & liana & seed & Donetsk Botanical Garden \\
\hline Celastraceae & C. orbiculatus Thunb. & liana & seed & Arboretum "Alexandria", Donetsk Botanical Garden \\
\hline Salicaceae & Populus balsamifera $\mathrm{L}$. & tree & seed, vegetative way & Donetsk Botanical Garden \\
\hline Salicaceae & P. $\times$ canadensis Moench & tree & seed, vegetative way & Donetsk Botanical Garden \\
\hline Salicaceae & P. trichocarpa Torr. \& A. Gray ex Hook. & tree & seed, vegetative way & Donetsk Botanical Garden \\
\hline Anacardiaceae & Rhus glabra L. & tree/shrub & seed, vegetative way & Botanical Garden of Ivan Franko National University of L'viv \\
\hline Anacardiaceae & *R. typhina $\mathrm{L}$. & tree & vegetative way & $\begin{array}{l}\text { Arboretum "Alexandria", Donetsk Botanical Garden, Botani- } \\
\text { cal Garden of Ivan Franko National University of L'viv }\end{array}$ \\
\hline Anacardiaceae & *R. typhina'Laciniata' & tree & vegetative way & Arboretum "Alexandria" \\
\hline Anacardiaceae & Toxicodendron pubescens Mill. & shrub & seed, vegetative way & Arboretum "Alexandria" \\
\hline Anacardiaceae & T. radicans $(\mathrm{L}$.$) O. Kuntze$ & shrub & seed, vegetative way & Donetsk Botanical Garden \\
\hline Aceraceae & Acer negundo L. & tree & seed & $\begin{array}{l}\text { Arboretum "Alexandria", Botanical Garden of Oles Hon- } \\
\text { char National University of Dnipro, Donetsk Botanical } \\
\text { Garden, O. V. Fomin Botanical Garden, Botanical Garden } \\
\text { of Ivan Franko National University of L'viv }\end{array}$ \\
\hline Aceraceae & $\begin{array}{l}\text { *A. platanoides L. f. atropurpurea } \\
\text { 'Krimson King' }\end{array}$ & tree & seed & Donetsk Botanical Garden \\
\hline Aceraceae & A. saccharinum $\mathrm{L}$. & tree & seed & Donetsk Botanical Garden \\
\hline $\begin{array}{l}\text { Hippocasta } \\
\text { naceae }\end{array}$ & Aesculus hippocastanum L. & tree & seed & $\begin{array}{c}\text { Arboretum "Alexandria", Donetsk Botanical Garden, } \\
\text { O. V. Fomin Botanical Garden }\end{array}$ \\
\hline Simaroubaceae & Ailanthus altissima (Mill.) Swingle & tree & seed, vegetative way & $\begin{array}{l}\text { Arboretum "Alexandria", Botanical Garden of Ivan Franko } \\
\text { National University of L'viv, Donetsk Botanical Garden }\end{array}$ \\
\hline Cornaceae & Cornus alba $\mathrm{L}$. & shrub & seed, vegetative way & Donetsk Botanical Garden \\
\hline Hydrangeaceae & Philadelphus coronarius L. & shrub & seed, vegetative way & Donetsk Botanical Garden \\
\hline Solanaceae & Lycium barbarum $\mathrm{L}$. & shrub & seed, vegetative way & Arboretum "Alexandria" \\
\hline Oleaceae & Fraxinus ornus L. & tree & seed & Nikitsky Botanical Garden \\
\hline Oleaceae & F. pennsylvanica Marshall & tree & seed & Donetsk Botanical Garden \\
\hline Oleaceae & Syringa vulgaris L. & shrub & seed, vegetative way & $\begin{array}{c}\text { Arboretum "Alexandria", Donetsk Botanical Garden, } \\
\text { O. V. Fomin Botanical Garden }\end{array}$ \\
\hline Bignoniaceae & *Campsis grandiflora (Thunb.) K. Schum. & liana & vegetative way & Arboretum "Alexandria" \\
\hline Bignoniaceae & ${ }^{*}$ C. radicans $(\mathrm{L}$.$) Seem.$ & liana & vegetative way & Arboretum "Alexandria" \\
\hline Caprifoliaceae & Lonicera caerulea $\mathrm{L}$. & shrub & seed & Donetsk Botanical Garden \\
\hline Caprifoliaceae & L. caprifolium $\mathrm{L}$. & shrub & seed & Arboretum "Alexandria" \\
\hline Caprifoliaceae & L. tatarica $\mathrm{L}$. & shrub & seed & Arboretum "Alexandria", Donetsk Botanical Garden \\
\hline Caprifoliaceae & Symphoricarpos albus (L.) S.F. Blake & shrub & seed, vegetative way & Donetsk Botanical Garden \\
\hline Apiaceae & Bupleurum fruticosum $\mathrm{L}$. & shrub & seed, egetative way & Nikitsky Botanical Garden \\
\hline Aracaceae & *Aralia elata (Miq.) Seem. & shrub & seed, vegetative way & Botanical Garden of Ivan Franko National University of L'viv \\
\hline
\end{tabular}

Note: * the species whose dispersion is known only beyond the framework of collections and expositions in botanical gardens and arboretums. 
The inspection of spontaneous spreading of intentionally introduced species from O. V. Fomin Botanical Garden of Taras Shevchenko National University of Kyiv resulted in issuing "The preliminary list of the species of the O. V. Fomin Botanical Garden, spreading beyond their place of cultivation" (Solomakha, 2007). This list contains 245 species, including 6 species - trees (Acer negundo, Aesculus hippocastanum, Juglans regia, Quercus rubra, Robinia pseudoacacia and Ulmus pumila), 2 species - shrubs (Sorbaria sorbifolia and Syringa vulgaris), 2 species lianas (Parthenocissus quinquefolia and Vitis vinifera).

45 woody species, including 13 aboriginal ones, are spontaneously spreading using seed dispersal and vegetative reproduction within the arboretum "Alexandria". Some non-native species do not reproduce via seed dispersal, but reproduce actively via vegetative reproduction: Campsis grandiflora, C. radicans, Rhus typhina, R. typhina 'Laciniata', Rubus odoratus, Syringa vulgaris, Toxicodendron pubescens (Doyko et al., 2014).

Woody plants, capable of reproducing spontaneously via either seed dispersal or vegetative reproduction, were found among intentionally introduced plants in the Botanical Garden of the Ivan Franko L'viv National University. These were four species of trees (Acer negundo, Ailanthus altissima, Robinia pseudoacacia and Thuja occidentalis) and three species of shrubs (Aralia elata, Rhus glabra, R. typhina) (Borsukevych \& Prokopiv, 2014). Among spontaneous species of the flora at the Botanical Garden of Oles Honchar National University of Dnipro, there are four known woody species (Acer negundo, Amorpha fruticosa, Gleditsia triacanthos and Parthenocissus quinquefolia). While analyzing the results of long-term observations, the authors noted the tendency towards the increase in their number and degree of naturalization within the garden (Tarasov et al., 1998). The "Catalogue" of plants of the M. M. Hryshko National Botanical Garden (Kokhno, 1997) does not have any data about seed dispersal. Occasionally there were some publications about seed dispersal of woody plants from its collections and expositions. Shinder (2013) considers the botanic-geographical area "Caucasus" to be the source of distribution of Caucasian species into anthropogenically altered locations within the garden. Celtis australis escaped the boundaries of the "Caucasus" area. Some Caucasian species have established stable spontaneous cenopopulations in the created simulated communities of this exposition. For instance, a rare species Quercus macranthera dominates in the growing stock of the planted dry oakery, constantly forming abundant natural self-sown plants. Periodic formation of abundant natural self-seeding of Parrotia subaequalis was recorded (Doroshenko et al., 2013).

The naturalization of plants in the oldest arboretums of the Nikitsky Botanical Garden must have occurred at the beginning of the 20th century. Without highlighting the collections of the garden, Stankov (1924 1925) noted the remarkable presence of the cultural element of the Mediterranean flora in the plant cover of the South Coast of Crimea. He mentioned 55 non-native species, which added unique Mediterranean charm to the landscape. S. S. Stankov observed the naturalization of the following 22 species in the Crimea personally: Ailanthus altissima, Berberis aquifolium, Bupleurum fruticosum, Cercis siliquastrum, Clematis flammula, Cydonia oblonga, Elaeagnus angustifolia, E. rhamnoides, Ficus carica, Fraxinus ornus, Ilex aquifolium, Laburnum anagyroides, Maclura pomifera, Morus alba, Olea europaea, Prunus armeniaca, P. cerasifera, P. cerasus, P. domestica, P. domestica subsp. insititia, Rhamnus alaternus and Spartium junceum. This list was later supplemented with Laurus nobilis, Lonicera caprifolium, Viburnum ti$n u s$, and S. S. Stankov doubted their going out of cultivation (Bagrikova, 2013). Obviously, we do not have any evidential materials to prove that all of these species have spread within the South Coast of Crimea after escaping the Nikitsky Botanical Garden. On the one hand, this institution had supplied many exotic trees, shrubs, and lianas to the market, being the only center of plant introduction in the Crimea, on the other hand, in different times, even with active dendrological collections of the Garden, amateurs of the garden art brought decorative woody plants to the Crimea, which could have spread beyond the locations of cultivation in different corners of the South Coast of Crimea. There is only one direct statement about two species (Bupleurum fruticosum, Fraxinus ornus), spreading within the nature reserve "Mys Martian" from the adjacent plant communities of the Nikitsky Botanical Garden (Bagrikova et al., 2014).
Therefore, 92 non-native woody species out of 49 genera and 28 families are spreading in collection areas and expositions or beyond them, but not escaping the boundaries of introduction centers in 6 abovementioned botanical gardens and arboretums. Table 2 presents 6 families, covering 5 or more species: Rosaceae -17 , Vitaceae -8 , Fabaceae -7 , Ranunculaceae -6 , Anacardiaceae -5 and Grossulaceae -5 . Spontaneous distribution of most species has been noted only in one garden (73), in 5 gardens there is a noted distribution of only Acer negundo, and in 4 - Robinia pseudoacacia. Half of these species have long been naturalized and become common elements of spontaneous flora. However, spontaneous distribution of 23 species is known only in controlled conditions of the botanical gardens and arboretums. For instance, these are Aralia elata, Parrotia subaequalis, Vitis coignetiae, Rhus typhina, R. typhina 'Laciniata', Rubus odoratus. Thus, the assumption, expressed by us regarding the centers of initial introduction of plants in Ukraine as the sources of distributing non-native woody species, has not been confirmed.

\section{The non-native woody species in the urban flora of Ukraine}

The degree of invasive activity of alien woody species in the framework of urban flora plays an important role in determining their part in the spontaneous flora of Ukraine. The main centers of naturalization of non-native species are cities with their suburbs, which unite parks, public gardens, green zone plantings, botanical gardens and arboretums. We have analyzed the lists of four recently thoroughly studied urban floras of such cities as Kyiv (Mosyakin \& Yavorska, 2002), Kryvyi Rih (Kuchrevskyi \& Shol, 2009), Uzhhorod (Protopopova \& Shevera, 2002), Kharkiv (Zvyagintseva, 2015), and combined floras of Sloviansk, Donetsk, Luhansk, and Mariupol, which have formed within industrial Donbas (Burda, 1997). These cities are in different regions of Ukraine and differ in the degree of environmental urbanization. Concluding the consideration of urban floras, we would like to highlight that the lists of alien species coincide in the main part (Table 3). This fact allowed us to combine woody species into a unified list to determine the degree of their naturalization. The authors of urban floras often added aboriginal species to them. They are absent in the combined list: Betula pendula Roth, B. pubescens Ehrh., Lonicera xylosteum L., Rubus idaeus L., Sambucus racemosa L., Sorbus aucuparia L., Tilia platyphyllos Scop., Viburnum lantana L., etc. Consideration was also given to the list of flora in Chernihiv, where the degree of naturalization was not indicated (Zavyalova, 2010). This urban flora contains about 50 non-native woody species, and the combined list of urban floras of Ukraine was added Phellodendron amurense and Spiraea $\times$ vanhouttei therefrom. The total list of alien woody species of 6 urban floras of Ukraine contains 80 species, 1 subspecies, and 1 hybrid (Table 3, 4). The picture of naturalization of non-native species in urban floras is very rich. They differ in terms of structure, degree of naturalization, species composition, and all of these are mutually related. The richest floras are noted for Kyiv, Kharkiv, Chernihiv, and the urban flora of Kryvyi Rih is not far behind them.

The degree of naturalization is also different. The only species, evaluated in all the floras as agriophyte, is Salix $\times$ blanda, and the one close to it is Acer negundo. The following species occur in one urban flora only: Ficus carica, Rubus macrophyllus, Toxicodendron radicans, Vitis labrusca. Agriophytes are concentrated in Kharkiv, hemiagriophytes and colonophytes - in Kyiv, ergasiophytes - in Kharkiv and Kryvyi Rih. Thus, urban floras have a high degree of naturalization of non-native woody species.

\section{The course of invasion of non-native woody species in the regional floras and in the floras of protected areas}

The regional studies, conducted by the specialists, headed by V. V. Protopopova, defined the following transformer species in the flora of 5 regions: Polissia - Robinia pseudoacacia (Protopopova et al., 2015); Bukovyna Cis-Carpathian region - Acer negundo, Robinia pseudoacacia (Protopopova et al., 2010); Middle Dnipro region - Acer negundo, Amorpha fruticosa, Robinia pseudoacacia (Protopopova et al., 
2014); North Black Sea region - Amorpha fruticosa, Elaeagnus angustifolia and Salix $\times$ blanda (Protopopova et al., 2009); South Coast of Crimea - Ailanthus altissima, Bupleurum fruticosum, Fraxinus ornus and Rhamnus alaternus (Protopopova et al., 2012). The authors distinguished 39 invasive species, including 13 woody species, in the flora of the Crimea. Robinia pseudoacacia is mentioned in four regions, Acer negundo, Amorpha fruticosa - in three, Elaeagnus angustifolia - in two and Salix $\times$ blanda - in only one region. According to our observations, the features of transformer species in the floras of 14 territories, which are subject to special protection in the Forest Steppe, are remarkable for 7 species: Acer negundo, Elaeagnus angustifolia, E. rhamnoides, Parthenocissus quinquefolia, $P$. vitacea, Robinia pseudoacacia and Salix $\times$ blanda. They occurred in at least 9 out of 14 floras, except for $E$. rhamnoides, noted in 3 floras only (Burda et al., 2015b). The study of alien flora species in 30 territories of the nature reserve fund in different natu- ral zones revealed the same 7 species of transformers. These are three trees: Acer negundo, Robinia pseudoacacia and Salix $\times$ blanda; 2 shrubs: Elaeagnus angustifolia and E. rhamnoides and 2 lianas: Parthenocissus quinquefolia and $P$. vitacea (Burda et al., 2015a). While determining the "transformer species" status, the main feature is stated as the ability to change the ecosystem completely. Five invasive species proper have been distinguished in the same place: Amorpha fruticosa, Morus alba, Prunus cerasus, $P$. serotina and $P$. virginiana. The floras of the nature reserve fund contain 16 woody species, which have naturalized (according to the scheme, accepted in this article, this notion is close to the term, further used by us, - "potentially invasive species"). In addition to the mentioned species, let us mention 31 more species, related to the ones which reproduce spontaneously, sporadically or in a single way in the reserve areas.

Table 3

The degree of naturalization and the occurrence of non-native woody species in some urban floras of Ukraine

\begin{tabular}{|c|c|c|c|c|c|c|c|}
\hline Species & Kyiv & Kryvyi Rih & Kharkiv & Uzhhorod & Donbas & Flora & Degree of naturalization \\
\hline Salix $\times$ blanda & agriophyte & agriophyte & agriophyte & agriophyte & agriophyte & 5 & 5 agriophytes \\
\hline Acer negundo & agriophyte & hemiagriophyte & agriophyte & hemiagriophyte & agriophyte & 5 & 3 agriophytes: 2 hemiagriophytes \\
\hline Berberis aquifolia & agriophyte & ergasiophyte & agriophyte & ergasiophyte & 0 & 4 & 2 agriophytes: 2 ergasiophytes \\
\hline Prunus cerasifera & 0 & ergasiophyte & agriophyte & agriophyte & 0 & 3 & 2 agriophytes: 1 ergasiophyte \\
\hline Amorpha fruticosa & agriophyte & hemiagriophyte & ergasiophyte & ergasiophyte & ergasiophyte & 5 & 1 agriophyte: 1 hemiagriophyte: 3 ergasiophytes \\
\hline Elaeagnus angustifolia & 0 & hemiagriophyte & agriophyte & ergasiophyte & epoecophyte & 4 & $\begin{array}{l}1 \text { agriophyte: } 1 \text { hemiagriophyte: } \\
1 \text { epoecophyte: } 1 \text { ergasiophyte }\end{array}$ \\
\hline Prunus serotina & agriophyte & ergasiophyte & 0 & 0 & 0 & 2 & 1 agriophyte: 1 ergasiophyte \\
\hline Parthenocissus vitacea & hemiagriophyte & 0 & agriophyte & 0 & 0 & 2 & 1 agriophyte: 1 hemiagriophyte \\
\hline Cydonia oblonga & 0 & 0 & agriophyte & 0 & 0 & 1 & 1 agriophyte \\
\hline Prumus domestica subsp. insititia & 0 & 0 & 0 & agriophyte & 0 & 1 & 1 agriophyte \\
\hline Robinia pseudoacacia & hemiagriophyte & hemiagriophyte & ergasiophyte & ergasiophyte & ergasiophyte & 5 & 2 hemiagriophytes: 3 ergasiophytes \\
\hline Lycium barbarum & hemiagriophyte & hemiagriophyte & epoecophyte & epoecophyte & epoecophyte & 5 & 2 hemiagriophytes: 3 epoecophytes \\
\hline Ulmus pumila & hemiagriophyte & hemiagriophyte & ergasiophyte & 0 & 0 & 3 & 2 hemiagriophytes: 1 ergasiophyte \\
\hline Caragana arborescens & hemiagriophyte & ergasiophyte & ergasiophyte & 0 & ergasiophyte & 4 & 1 hemiagriophyte: 3 ergasiophytes \\
\hline Acer saccharinum & hemiagriophyte & ergasiophyte & ergasiophyte & 0 & 0 & 3 & 1 hemiagriophyte: 2 ergasiophytes \\
\hline Quercus rubra & hemiagriophyte & ergasiophyte & ergasiophyte & 0 & 0 & 3 & 1 hemiagriophyte: 2 ergasiophytes \\
\hline Ptelea trifoliata & hemiagriophyte & ergasiophyte & 0 & 0 & 0 & 2 & 1 hemiagriophyte: 1 ergasiophyte \\
\hline Elaeagnus commutata & 0 & hemiagriophyte & 0 & 0 & 0 & 1 & 1 hemiagriophyte \\
\hline Morus alba & epoecophyte & ergasiophyte & colonophyte & 0 & epoecophyte & 4 & 2 epoecophytes: 1 ergasiophyte: 1 colonophyte \\
\hline Gleditsia triacanthos & colonophyte & ergasiophyte & epoecophyte & ergasiophyte & 0 & 4 & 1 epoecophyte: 2 ergasiophytes: 1 colonophyte \\
\hline Fraxinus pennsylvanica & epoecophyte & epoecophyte & ergasiophyte & 0 & 0 & 3 & 2 epoecophytes: 1 ergasiophyte \\
\hline Elaeagnus rhamnoides & 0 & epoecophyte & epoecophyte & ergasiophyte & 0 & 3 & 2 epoecophytes: 1 ergasiophyte \\
\hline Lonicera tatarica & colonophyte & epoecophyte & epoecophyte & 0 & 0 & 3 & 2 epoecophytes: 1 colonophyte \\
\hline Populus deltoides & colonophyte & epoecophyte & epoecophyte & 0 & 0 & 3 & 2 epoecophytes: 1 colonophyte \\
\hline Parthenocissus quinquefolia & colonophyte & epoecophyte & 0 & ergasiophyte & 0 & 3 & 1 epoecophyte: 1 ergasiophyte: 1 colonophyte \\
\hline Ailanthus altissima & epoecophyte & colonophyte & ergasiophyte & 0 & 0 & 3 & 1 epoecophyte: 1 ergasiophyte: 1 colonophyte \\
\hline Spiraea salicifolia & epoecophyte & 0 & ergasiophyte & 0 & 0 & 2 & 1 epoecophyte: 1 ergasiophyte \\
\hline Symphoricarpos albus & colonophyte & 0 & epoecophyte & 0 & 0 & 2 & 1 epoecophyte: 1 colonophyte \\
\hline Parthenocissus tricuspidata & 0 & 0 & epoecophyte & 0 & 0 & 1 & 1 epoecophyte \\
\hline Cornus sericea & 0 & 0 & epoecophyte & 0 & 0 & 1 & 1 epoecophyte \\
\hline Juglans regia & ephemerophyte & ergasiophyte & ergasiophyte & ergasiophyte & 0 & 4 & 3 ergasiophytes: 1 ephemerophyte \\
\hline Prunus armeniaca & colonophyte & ergasiophyte & ergasiophyte & 0 & ergasiophyte & 4 & 3 ergasiophytes: 1 colonophyte \\
\hline P. cerasus & colonophyte & ergasiophyte & ergasiophyte & 0 & ergasiophyte & 4 & 3 ergasiophytes: 1 colonophyte \\
\hline Syringa vulgaris & colonophyte & colonophyte & ergasiophyte & ergasiophyte & 0 & 4 & 2 ergasiophytes: 2 colonophyte \\
\hline Vitis vinifera & ephemerophyte & ergasiophyte & ergasiophyte & 0 & ergasiophyte & 4 & 3 ergasiophytes: 1 ephemerophyte \\
\hline Aesculus hippocastanum & 0 & ergasiophyte & ergasiophyte & ergasiophyte & 0 & 3 & 3 ergasiophytes \\
\hline Ribes uva-crispa & 0 & ergasiophyte & ergasiophyte & 0 & ergasiophyte & 3 & 3 ergasiophytes \\
\hline Malus domestica & colonophyte & ergasiophyte & ergasiophyte & 0 & 0 & 3 & 2 ergasiophytes: 1 colonophyte \\
\hline Prunus mahaleb & colonophyte & ergasiophyte & 0 & 0 & ergasiophyte & 3 & 2 ergasiophytes: 1 colonophyte \\
\hline Catalpa bignonioides & 0 & 0 & ergasiophyte & ergasiophyte & 0 & 2 & 2 ergasiophytes \\
\hline Juglans nigra & 0 & ergasiophyte & ergasiophyte & 0 & 0 & 2 & 2 ergasiophytes \\
\hline Populus bolleana & 0 & ergasiophyte & ergasiophyte & 0 & 0 & 2 & 2 ergasiophytes \\
\hline P. nigra var. italica & 0 & ergasiophyte & ergasiophyte & 0 & 0 & 2 & 2 ergasiophytes \\
\hline Aronia melanocarpa & colonophyte & 0 & ergasiophyte & 0 & 0 & 2 & 1 ergasiophyte: 1 colonophyte \\
\hline Malus baccata & colonophyte & 0 & ergasiophyte & 0 & 0 & 2 & 1 ergasiophyte: 1 colonophyte \\
\hline Celtis occidentalis & colonophyte & ergasiophyte & 0 & 0 & 0 & 2 & 1 ergasiophyte: 1 colonophyte \\
\hline Lonicera caprifolium & colonophyte & 0 & 0 & ergasiophyte & 0 & 2 & 1 ergasiophyte: 1 colonophyte \\
\hline Rhus typhina & 0 & colonophyte & ergasiophyte & 0 & 0 & 2 & 1 ergasiophyte: 1 colonophyte \\
\hline Aesculus flava & 0 & 0 & ergasiophyte & 0 & 0 & 1 & 1 ergasiophyte \\
\hline Castanea sativa & 0 & 0 & 0 & ergasiophyte & 0 & 1 & 1 ergasiophyte \\
\hline Crataegus sanguinea & 0 & 0 & ergasiophyte & 0 & 0 & 1 & 1 ergasiophyte \\
\hline Juglans cinerea & 0 & ergasiophyte & 0 & 0 & 0 & 1 & 1 ergasiophyte \\
\hline Populus suaveolens & 0 & 0 & ergasiophyte & 0 & 0 & 1 & 1 ergasiophyte \\
\hline Persica vulgaris & 0 & ergasiophyte & 0 & 0 & 0 & 1 & 1 ergasiophyte \\
\hline Prunus virginiana & 0 & 0 & ergasiophyte & 0 & 0 & 1 & 1 ergasiophyte \\
\hline
\end{tabular}




\begin{tabular}{|c|c|c|c|c|c|c|c|}
\hline Species & Kyiv & Kryvyi Rih & Kharkiv & Uzhhorod & Donbas & Flora & Degree of naturalization \\
\hline P. domestica & 0 & ergasiophyte & 0 & 0 & 0 & 1 & 1 ergasiophyte \\
\hline Tilia americana & 0 & 0 & ergasiophyte & 0 & 0 & 1 & 1 ergasiophyte \\
\hline Colutea arborescens & 0 & ergasiophyte & 0 & 0 & 0 & 1 & 1 ergasiophyte \\
\hline Cornus alba & 0 & ergasiophyte & 0 & 0 & 0 & 1 & 1 ergasiophyte \\
\hline Philadelphus coronarius & 0 & 0 & ergasiophyte & 0 & 0 & 1 & 1 ergasiophyte \\
\hline Salix babylonica & 0 & 0 & ergasiophyte & 0 & 0 & 1 & 1 ergasiophyte \\
\hline Ribes aureum & 0 & ergasiophyte & 0 & 0 & 0 & 1 & 1 ergasiophyte \\
\hline R. rubrum & 0 & 0 & 0 & 0 & ergasiophyte & 1 & 1 ergasiophyte \\
\hline Rosa rugosa & colonophyte & 0 & ergasiophyte & 0 & 0 & 2 & 1 colonophyte \\
\hline Robinia neomexicana & 0 & 0 & ergasiophyte & 0 & 0 & 1 & 1 ergasiophyte \\
\hline Robinia viscosa & 0 & ergasiophyte & 0 & 0 & 0 & 1 & 1 ergasiophyte \\
\hline Juglans mandshurica & colonophyte & 0 & 0 & 0 & 0 & 1 & 1 colonophyte \\
\hline Amelanchier ovalis & colonophyte & 0 & 0 & 0 & 0 & 1 & 1 colonophyte \\
\hline Berberis thunbergii & colonophyte & 0 & 0 & 0 & 0 & 1 & 1 colonophyte \\
\hline B. vulgaris & colonophyte & 0 & 0 & 0 & 0 & 1 & 1 colonophyte \\
\hline Populus balsamifera & colonophyte & 0 & 0 & 0 & 0 & 1 & 1 colonophyte \\
\hline Quercus palustris & colonophyte & 0 & 0 & 0 & 0 & 1 & 1 colonophyte \\
\hline Sorbaria sorbifolia & colonophyte & 0 & 0 & 0 & 0 & 1 & 1 colonophyte \\
\hline Spiraea douglasii & colonophyte & 0 & 0 & 0 & 0 & 1 & 1 colonophyte \\
\hline Physocarpus opulifolius & colonophyte & 0 & 0 & 0 & 0 & 1 & 1 colonophyte \\
\hline Cotoneaster melanocarpus & colonophyte & 0 & 0 & 0 & 0 & 1 & 1 colonophyte \\
\hline Clematis jackmanii & colonophyte & 0 & 0 & 0 & 0 & 1 & 1 colonophyte \\
\hline C. viticella & colonophyte & 0 & 0 & 0 & 0 & 1 & 1 colonophyte \\
\hline Ficus carica & ephemerophyte & 0 & 0 & 0 & 0 & 1 & 1 ephemerophyte \\
\hline Rubus macrophyllus & 0 & 0 & 0 & 0 & ephemerophyte & 1 & 1 ephemerophyte \\
\hline Toxicodendron radicans & ephemerophyte & 0 & 0 & 0 & 0 & 1 & 1 ephemerophyte \\
\hline Vitis labrusca & ephemerophyte & 0 & 0 & 0 & 0 & 1 & 1 ephemerophyte \\
\hline Total & 49 & 44 & 49 & 18 & 15 & - & - \\
\hline
\end{tabular}

Note: here and in Tables 4 and 7 " $0 "$ - the species is absent.

Table 4

The degree of naturalization of woody exotic species in some urban floras of Ukraine

\begin{tabular}{|c|c|c|c|c|c|c|}
\hline $\begin{array}{c}\text { Degree } \\
\text { of naturalization }\end{array}$ & Kyiv & Kryvyi Rih & Kharkiv & Uzhhorod & Donbas & Total* \\
\hline Agriophyte & 5 & 1 & 7 & 3 & 2 & 10 \\
\hline Hemiagriophyte & 8 & 7 & 0 & 1 & 0 & 8 \\
\hline Epoecophyte & 4 & 5 & 8 & 1 & 3 & 12 \\
\hline Ergasiophyte & 0 & 28 & 33 & 13 & 9 & 36 \\
\hline Colonophyte & 27 & 3 & 1 & 0 & 0 & 12 \\
\hline Ephemerophyte & 5 & 0 & 0 & 0 & 1 & 4 \\
\hline Total & 49 & 44 & 49 & 18 & 15 & 82 \\
\hline
\end{tabular}

Note: $*$ - this column presents the data about the number of species in specific categories of the total list.

68 exotic species have spontaneously spread within the South Coast of Crimea. These are 27 agriophytes: Acer negundo, Ailanthus altissima, Berberis aquifolia, Bupleurum fruticosum, Buxus sempervirens, Cercis siliquastrum, Clematis flammula, Colutea orientalis, Cydonia oblonga, Daphne laureola, Elaeagnus angustifolia, Ficus carica, Fraxinus ornus, Laburnum anagyroides, Lonicera etrusca, Lycium barbarum, Malus domestica, Platycladus orientalis, Prunus cerasifera, P. dulcis, Ptelea trifoliata, Pueraria montana var. lobata, Pyrus communis, Quercus ilex, Rhamnus alaternus, Viburnum tinus and Vitis vinifera; 40 colonophytes: Abies pinsapo, Amorpha fruticosa, Buddleja davidii, Caragana arborescens, Castenea sativa, Catalpa bignonioides, Cedrus atlantica, C. deodara, Celtis australis, C. caucasica, Cladrastis kentukea, Colutea arborescens, Cotoneaster glaucophyllus, Cupressus sempervirens, Dyospyros lotus, Gleditsia triacanthos, Koelreuteria paniculata, Prunus laurocerasus, Laurus nobilis, Lonicera caprifolium, L. standishii, L. tatarica, Machura pomifera, Morus alba, M. nigra, M. rubra, Olea europaea, Parthenocissus quinquefolia, Prunus armeniaca, P. domestica, $P$. vulgaris, Pyracantha rogersiana, Ribes aureum, $R$. rubrum, $R$. spicatum, Robinia pseudoacacia, Sophora japonica, Spartium junceum, Syringa vulgaris and Zelkova carpinifolia and ephemerophyte Prunus cerasus.

18 exotic woody species penetrated the flora of the Yalta Mountain-Forest Natural Reserve. All of them are agriophytes - 13 species, and colonophytes - 5 species (Bagrikova \& Bondarenko, 2015). A number of alien woody species form local populations of normal type in the native communities of "Mys Martian" nature reserve: Bupleurum fruticosum, Buxus sempervirens, Fraxinus ornus, Laburnum anagyroides and Prunus cerasifera (Bagrikova et al., 2014). In addition to the data about naturalization of plants in the botanical gardens, cities and nature reserve fund, we have considered articles about their separate records (Tyshchenko et al., 2013; Burda, 2014). It has also been noted that Acer negundo and Robinia pseudoacacia are viewed as diagnostic species of the synanthropic Robinietea class, stable components of Salicetea purpureae class, capable of intruding into the phytocenoces of QuercoFagetea class causing structural disruption. Elaeagnus angustifolia and E. commutata are transformer species in Steppe and Circum-Pontic regions, conditioning the colonization of river basins, changing the grass cover of salinized coastal depressions (Abduloyeva \& Karpenko, 2009). Ailanthus altissima, Celtis occidentalis, Juglans cinerea, J. mandshurica, J. regia, Prunus serotina, P. virginiana, Ribes uva-crispa, spread spontaneously from forest culture in the nature reserve territories of the Forest-Steppe, also in the habitats of G type (forests and shrubs), Acer negundo and Amorpha fruticosa are involved in the cenoses of Rhamno-Prunetea class (Pashkevych \& Burda, 2017).

\section{The invasion of alien woody species into spontaneous flora in Ukraine}

Therefore, 182 non-native woody species (172 species, 1 subspecies, 4 varieties and 5 hybrids) have been distinguished in the spontaneous flora of Ukraine (Tables 5, 6). This list is obviously incomplete. Only the articles in general access have been considered. The archive data on thorough studies of the course of initial introduction are unaccessible. Herbarium labels do not always highlight the origin of herborized samples, collected in the botanical gardens and arboretums. On the one hand, the compilation of a more precise list of woody exotic species is hindered by the absence of a unified inventory of collection funds and database of the course of naturalization of these species, and, on the other hand, the naturalization process is not over. On the contrary, it is getting stronger. Plant invasion is an extremely dynamic process. However, the presented list gives a general idea about the composition and character of non-native woody trees in the domestic flora.

71 alien completely naturalized plants have been differentiated (66 species, 1 subspecies, 1 variety and 3 hybrids). They belong to 47 genera and 28 families of two divisions - Pinophyta and Magnoliophyta (Table 5). This group presents the highest risk for the local diversity of species: 12 of them are transformers, 8 are invasive proper, 29 - potentially invasive, 22 - naturalized species, whose invasive activity has not been manifested. In terms of life-forms, the list of alien woody species contains 
Table 5

The invasive activity of alien woody species in spontaneous flora of Ukraine

\begin{tabular}{|c|c|c|c|c|c|c|}
\hline Family & Taxon & Life-form & Spread & Degree of naturalization* & Occurrence & Invasive activity \\
\hline \multicolumn{7}{|c|}{ Pinophyta } \\
\hline Cupressaceae & Platycladus orientalis (L.) Franco & tree/shrub & seed & agriophyte $_{\mathrm{c}}$ & rare & naturalized \\
\hline \multicolumn{7}{|c|}{ Magnoliophyta } \\
\hline Berberidaceae & Berberis aquifolia Pursh & shrub & seed, vegetative way & agriophyte & local & invasive \\
\hline Berberidaceae & B. vulgaris L. & shrub & seed, vegetative way & epoecophyte & sporadic & naturalized \\
\hline Ranunculaceae & Clematis flammula $\mathrm{L}$. & liana & seed, vegetative way & agriophyte $_{c}$ & sporadic & potentially invasive \\
\hline Buxaceae & Buxus sempervirens L. & shrub & seed & agriophyte $_{c}$ & local & potentially invasive \\
\hline Grossulariaceae & Ribes uva-crispa $\mathrm{L}$. & shrub & seed, vegetative way & ergasiophyte & local & potentially invasive \\
\hline Vitaceae & Parthenocissus quinquefolia (L.) Planch. & liana & seed, vegetative way & $\begin{array}{l}\text { colonophyte }_{c} \\
\text { epoecophyte }\end{array}$ & common & transformer \\
\hline Vitaceae & P. tricuspidata (Siebold \& Zucc.) Planch. & liana & seed, vegetative way & epoecophyte & rare & naturalized \\
\hline Vitaceae & P. vitacea (Knerr) Hitchc. & liana & seed, vegetative way & agriophyte & common & transformer \\
\hline Vitaceae & Vitis vinifera $\mathrm{L}$. & liana & seed, vegetative way & agriophyte $_{\mathrm{c}}$, epoecophyte & common & invasive \\
\hline Fabaceae & Amorpha fruticosa $\mathrm{L}$. & shrub & seed, vegetative way & agriophyte, colonophyte ${ }_{c}$ & common & ttransformer \\
\hline Fabaceae & Caragana arborescens Lam. & shrub & seed & colonophyte $_{\mathfrak{c}}$, hemiagriophyte & common & naturalized \\
\hline Fabaceae & Cercis siliquastrum $\mathrm{L}$. & tree/shrub & seed & agriophyte $_{c}$ & rare & naturalized \\
\hline Fabaceae & Colutea orientalis Mill. & shrub & seed & agriophyte $_{\mathrm{c}}$ & local & invasive \\
\hline Fabaceae & Gleditsia triacanthos L. & tree & seed & $\begin{array}{l}\text { colonophyte, } \\
\text { epoecophyte }\end{array}$ & sporadic & naturalized \\
\hline Fabaceae & Laburnum anagyroides Medik. & shrub & seed & agriophyte $_{c}$ & local & potentially invasive \\
\hline Fabaceae & $\begin{array}{l}\text { Pueraria montana var. lobata (Willd.) } \\
\text { Sanjappa \& Prade }\end{array}$ & liana & seed, vegetative way & agriophyte $_{c}$ & local & potentially invasive \\
\hline Fabaceae & Robinia pseudoacacia $\mathrm{L}$. & tree & seed, vegetative way & colonophyte , agriophyte & common & transformer \\
\hline Rosaceae & Amelanchier spicata (Lam.) K. Koch & tree & seed, vegetative way & agriophyte & sporadic & potentially invasive \\
\hline Rosaceae & Cydonia oblonda Mill. & tree/shrub & seed, vegetative way & agriophyte & common & potentially invasive \\
\hline Rosaceae & Malus domestica Borkh. & tree & seed, vegetative way & agriophyte & common & potentially invasive \\
\hline Rosaceae & Physocarpus opulifolius (L.) Maxim. & shrub & seed, vegetative way & epoecophyte & common & naturalized \\
\hline Rosaceae & Prunus armeniaca $\mathrm{L}$. & tree & seed, vegetative way & colonophyte $_{\mathrm{c}}$, epoecophyte & common & naturalized \\
\hline Rosaceae & P. cerasus L. & tree & seed, vegetative way & ephemerophyte $_{c}$, epoecophyte & common & naturalized \\
\hline Rosaceae & P. cerasifera Ehrh. & tree/shrub & seed, vegetative way & agriophyte & common & invasive \\
\hline Rosaceae & P. domestica L. & tree & seed, vegetative way & colonophyte ${ }_{c}$, ergasiophyte & common & naturalized \\
\hline Rosaceae & $\begin{array}{l}\text { P. domestica subsp. insititia (L.) } \\
\text { Bonnier \& Layens }\end{array}$ & tree/shrub & seed, vegetative way & agriophyte & common & potentially invasive \\
\hline Rosaceae & P. dulcis (Mill.) D.A. Webb & tree & seed & agriophyte $_{c}$ & local & potentially invasive \\
\hline Rosaceae & P. serotina Ehrh. & tree/shrub & seed, vegetative way & agriophyte & common & invasive \\
\hline Rosaceae & P. virginiana $\mathrm{L}$. & tree & seed, vegetative way & ergasiophyte & common & potentially invasive \\
\hline Rosaceae & Pyrus communis L. & tree & seed, vegetative way & agriophyte & common & naturalized \\
\hline Rosaceae & Rosa rugosa Thunb. & shrub & seed, vegetative way & ergasiophyte & common & naturalized \\
\hline Rosaceae & Sorbaria sorbifolia (L.) A. Braun & shrub & seed, vegetative way & epoecophyte & common & potentially invasive \\
\hline Elaeagnaceae & Elaeagnus angustifolia $\mathrm{L}$. & tree/shrub & seed, vegetative way & agriophyte & common & transformer \\
\hline Elaeagnaceae & E. rhamnoides (L.) A. Nelson & shrub & seed,vegetative way & agriophyte & common & transformer \\
\hline Elaeagnaceae & E. commutata Bernh. ex Rydb. & tree & seed, vegetative way & hemiagriophyte & rare & potentially invasive \\
\hline Rhamnaceae & Rhamnus alaternus L. & shrub & seed, vegetative way & agriophyte $_{\mathrm{c}}$ & local & trnsformer \\
\hline Ulmaceae & Ulmus pumila $\mathrm{L}$. & tree & seed, vegetative way & hemiagriophyte & common & potentially invasive \\
\hline Moraceae & Ficus carica L. & tree/shrub & seed & $\begin{array}{l}\text { agriophyte }_{c,} \\
\text { ephemerophyte }\end{array}$ & $\begin{array}{l}\text { local } \\
\text { unique }\end{array}$ & potentially invasive \\
\hline Moraceae & Morus alba $\mathrm{L}$. & tree & seed & $\begin{array}{l}\text { colonophyte } \\
\text { epoecophyte }\end{array}$ & common & potentially invasive \\
\hline Fagaceae & Quercus ilex L. & tree & seed & agriophyte $_{\mathrm{c}}$ & local & invasive \\
\hline Fagaceae & Q. rubra L. & tree & seed & emiagriophyte & local & potentially invasive \\
\hline Celastraceae & Celastrus scandens L. & liana & seed, vegetative way & epoecophyte & rare & potentially invasive \\
\hline Salicaceae & Populus balsamifera $\mathrm{L}$. & tree & seed, vegetative way & ergasiophyte & rare & naturalized \\
\hline Salicaceae & P. bolleana Lauche & tree & seed, vegetative way & ergasiophyte & common & naturalized \\
\hline Salicaceae & P. $\times$ canadensis Moench & tree & seed, vegetative way & epoecophyte & common & naturalized \\
\hline Salicaceae & P. deltoides Marshall & tree & seed, vegetative way & epoecophyte & common & naturalized \\
\hline Salicaceae & P. nigra var. italica Münchh & tree & seed, vegetative way & ergasiophyte & common & naturalized \\
\hline Salicaceae & P. suaveolens Fisch. & tree & seed, vegetative way & ergasiophyte & common & naturalized \\
\hline Salicaceae & P. richocarpa Torr. \& A. Gray ex Hook. & tree & seed, vegetative way & ergasiophyte & common & naturalized \\
\hline Salicaceae & Salix $\times$ babilonica $\mathrm{L}$. & tree & seed, vegetative way & ergasiophyte & common & naturalized \\
\hline Salicaceae & S. $\times$ blanda Andersson & tree & seed, vegetative way & agriophyte & common & trnsformer \\
\hline Anacardiaceae & Toxicodendron radicans (L.) O. Kuntze & shrub & seed, vegetative way & ergasiophyte & local & potentially invasive \\
\hline Aceraceae & Acer negundo L. & tree & seed & agriophyte & common & transformer \\
\hline Rutaceae & Ptelea trifoliata $\mathrm{L}$. & shrub & seed, vegetative way & agriophyte $_{c}$, hemiagriophyte & common & potentially invasive \\
\hline Simaroubaceae & Ailanthus altissima (Mill.) Swingle & tree & seed, vegetative way & agriophyte $_{\mathrm{c}}$, epoecophyte & common & trnsformer \\
\hline Tiliaceae & Tilia americana $\mathrm{L}$. & tree & seed & ergasiophyte & common & naturalized \\
\hline Thymelaeaceae & Daphne laureola L. & shrub & seed, vegetative way & agriophyte $_{\mathrm{c}}$ & local & invasive \\
\hline Cornaceae & Cornus alba $\mathrm{L}$. & shrub & seed, vegetative way & ergasiophyte & common & potentially invasive \\
\hline Cornaceae & C. sericea L. & shrub & seed, vegetative way & epoecophyte & common & potentially invasive \\
\hline Hydrangeaceae & Philadelphus coronarius L. & shrub & seed, vegetative way & ergasiophyte & common & naturalized \\
\hline Solanaceae & Lycium barbarum $\mathrm{L}$. & shrub & seed, vegetative way & agriophyte $_{c}$, epoecophyte & common & ins potentially invasive \\
\hline Oleaceae & Fraxinus americana L. & tree & seed & epoecophyte & common & naturalized \\
\hline Oleaceae & F. ornus L. & tree & seed & agriophyte $_{\mathrm{c}}$ & local & transformer \\
\hline
\end{tabular}




\begin{tabular}{|c|c|c|c|c|c|c|}
\hline Family & Taxon & Life-form & Spread & Degree of naturalization* & Occurrence & Invasive activity \\
\hline Oleaceae & F. pennsylvanica Marshall & tree & seed & epoecophyte & common & potentially invasive \\
\hline Oleaceae & Syringa vulgaris L. & shrub & seed, vegetative way & colonophyte $_{c}$, ergasiophyte & common & naturalized \\
\hline Viburnaceae & Viburnum tinus L. & shrub & seed, vegetative way & agriophyte $_{c}$ & local & invasive \\
\hline Caprifoliaceae & Lonicera etrusca Santi & shrub & seed & agriophyte $_{c}$ & local & potentially invasive \\
\hline Caprifoliaceae & L. tatarica L. & shrub & seed & colonophyte , epoecophyte & common & naturalized \\
\hline Caprifoliaceae & Symphoricarpos albus (L.) S. F. Blake & shrub & seed, vegetative way & epoecophyte & common & naturalized \\
\hline Apiaceae & Bupleurum fruticosum $\mathrm{L}$. & shrub & seed, vegetative way & agriophyte $_{c}$ & local & transformer \\
\hline
\end{tabular}

Note: *-here and in Table 6 interlinear "c" marks "Crimea".

The prevailing majority of alien woody species have both seed dispersal and vegetative reproduction (56 species). Vegetative reproduction was not observed in nature for 15 species. In terms of the naturalization degree of alien woody species, 35 species are agriophytes, 5 hemiagriophytes, 16 - epoecophytes, 18 - ergasiophytes, 15 - colonophytes and 1 -ephemerophyte.

A number of species in specific regions have acquired different degrees of naturalization. For instance, Ficus carica is an agriophyte in the flora of the South Coast of Crimea, but an ephemerophyte - in the urban flora of Kyiv; Ailanthus altissima and Lycium barbarum are agriophytes in the Crimea, and in the rest of the territory they are epoecophytes. At the same time, Caragana arborescens and Robinia pseudoacacia have not naturalized completely on the peninsula, and have the status of colonophytes, while on the mainland they are hemiagriophyte and agriophyte, respectively, etc. The following species spread as agriophytes only on the Crimean Peninsula: Bupleurum fruticosum, Buxus sempervirens, Clematis flammula, Cercis siliquastrum, Colutea orientalis, Daphne laureola, Laburnum anagyroides, Lonicera etrusca, Platycladus orientalis, Prumus dulcis, Pueraria montana var. lobata, Quercus ilex and Rhammus alaternus, etc.
The naturalization non-native woody species in plant communities in Ukraine

There are 111 non-native woody species whose naturalization has not completed yet (107 species, 2 varieties, and 2 hybrids), out of 65 genera and 35 families, 2 divisions - Pinophyta and Magnoliophyta (Table 6). In terms of life-forms, these are trees (45 species), shrubs (38 species), lianas (19 species), 9 have the life-form of both a tree and a shrub; they have seed dispersal (61), vegetative way of reproduction (4), or spread via both ways (46). The degree of occurrence of non-native species is reflected by the following spectrum: 7 - sporadic, 17 - local, 51 - occurring in 3-5 (7) localities, 13 - unique and 23 species which have dispersed by seed dispersal or vegetative way, having escaped the collections and expositions only in botanical gardens and arboretums. The species of this group are mainly ephemerophytes by the degree of naturalization. However, some of them are already acquiring the status of colonophytes: Allbizia julibrissin, Sophora japonica, Spartium junceum, while Ficus carica and Juglans regia on the South Coast of Crimea are even agriophytes (Bagrikova, 2013).

Table 6

Non-native naturalizing woody species of spontaneous flora of Ukraine

\begin{tabular}{|c|c|c|c|c|c|c|}
\hline Family & Taxon & Life-form & Spread & $\begin{array}{c}\text { Degree } \\
\text { of naturalization }\end{array}$ & Occurrence & $\begin{array}{c}\text { Stage } \\
\text { of naturalization }\end{array}$ \\
\hline \multicolumn{7}{|c|}{ Pinophyta } \\
\hline Pinaceae & Abies pinsapo Boiss. & tree & seed & colonophyte $_{c}$ & rare & reproduction \\
\hline Pinaceae & Cedrus atlantica (Endl.) Manetti ex Carrière & tree & seed & colonophyte $_{c}$ & rare & reproduction \\
\hline Pinaceae & C. deodara (Roxb. ex D. Don) G. Don & tree & seed & colonophyte $_{c}$ & rare & reproduction \\
\hline Pinaceae & Larix decidua Mill. & tree & seed & ephemerophyte & controlled & reproduction \\
\hline Cupressaceae & Cupressus sempervirens L. & tree & seed & colonophyte $_{c}$ & rare & reproduction \\
\hline Cupressaceae & Thuja occidentalis L. & tree/shrub & seed & ephemerophyte & controlled & reproduction \\
\hline \multicolumn{7}{|c|}{ Magnoliophyta } \\
\hline Aristolochiaceae & Aristolochia macrophylla Lam. & liana & seed & ephemerophyte & unique & records \\
\hline Lauraceae & Laurus nobilis $\mathrm{L}$. & tree/shrub & seed & colonophyte $_{c}$ & rare & reproduction \\
\hline Berberidaceae & Berberis thunbergasiophyteii DC. & shrub & seed, vegetative way & ephemerophyte & controlled & survival \\
\hline Magnoliaceae & Liriodendron thunbergii DC. & tree & seed, vegetative way & ephemerophyte & unique & records \\
\hline Ranunculaceae & Clematis gouriana Roxb. ex DC. & liana & seed, vegetative way & ephemerophyte & controlled & establishing \\
\hline Ranunculaceae & C.jackmanii T. Moore. & liana & seed, vegetative way & ephemerophyte & controlled & establishing \\
\hline Ranunculaceae & C. ligusticifolia Nutt & liana & seed, vegetative way & ephemerophyte & controlled & establishing \\
\hline Ranunculaceae & C. tangutica (Maxim.) Korsh. & liana & seed, vegetative way & ephemerophyte & controlled & establishing \\
\hline Ranunculaceae & C. vitalba $\mathrm{L}$. & liana & seed, vegetative way & colonophyte & rare & establishing \\
\hline Ranunculaceae & C. viticella $\mathrm{L}$. & liana & seed, vegetative way & ephemerophyte & controlled & establishing \\
\hline Platanaceae & Platanus acerifolia (Aiton) Willd. & tree & seed & $\begin{array}{l}\text { colonophyte }_{\mathrm{c}} \\
\text { ephemerophyte }\end{array}$ & unique & records \\
\hline Hamamelidaceae & $\begin{array}{l}\text { Parrotia subaequalis (Hung T. Chang) } \\
\text { R.M. Hao \& H.T. Wei }\end{array}$ & tree/shrub & seed & ephemerophyte & controlled & reproduction \\
\hline Grossulariaceae & Ribes americanum Mill. & shrub & seed & ephemerophyte & controlled & reproduction \\
\hline Grossulariaceae & R. aureum Pursh & shrub & seed & colonophyte $_{c}$ & rare & reproduction \\
\hline Grossulariaceae & R. europaea (L.) Mill. & shrub & seed & ephemerophyte & rare & reproduction \\
\hline Grossulariaceae & R. rubrum L. & shrub & seed & colonophyte $_{c}$ & rare & reproduction \\
\hline Grossulariaceae & R. spicatum Robson & shrub & seed & colonophyte & rare & reproduction \\
\hline Vitaceae & Ampelopsis aconitifolia Bunge & liana & seed, vegetative way & ephemerophyte & controlled & survival \\
\hline Vitaceae & $\begin{array}{l}\text { A. delavayana var. glabra (Diels \& Gilg) } \\
\text { C.L. Li }\end{array}$ & liana & seed, vegetative way & ephemerophyte & controlled & survival \\
\hline Vitaceae & A. bodinieri (H. Lév. \& Vaniot) Rehder & liana & seed, vegetative way & ephemerophyte & controlled & survival \\
\hline Vitaceae & $\begin{array}{l}\text { A. glandulosa var. brevipedunculata (Max- } \\
\text { im.) Momiy }\end{array}$ & liana & seed, vegetative way & ephemerophyte & controlled & survival \\
\hline Vitaceae & Vitis coignetiae Bull. ex Planch & liana & seed, vegetative way & ephemerophyte & controlled & survival \\
\hline Vitaceae & V. labrusca L. & liana & seed, vegetative way & colonophyte & rare & reproduction \\
\hline Fabaceae & Allbizia julibrissin Durazz & tree & seed, vegetative way & ephemerophyte $_{\mathrm{c}}$ & rare & survival \\
\hline Fabaceae & Cladrastis kentukea (Dum. Cours.) Rudd & shrub & seed & colonophyte & sporadic & establishing \\
\hline Fabaceae & Colutea arborescens L. & shrub & seed & colonophyte $_{c}$ & rare & survival \\
\hline Fabaceae & Gymnocladus dioica (L.) K. Koch & tree & seed & ephemerophyte & rare & survival \\
\hline Fabaceae & Halimodendron halodendron (Pall.) Voss & shrub & seed & colonophyte & local & establishing \\
\hline
\end{tabular}




\begin{tabular}{|c|c|c|c|c|c|c|}
\hline Family & Taxon & Life-form & Spread & $\begin{array}{c}\text { Degree } \\
\text { of naturalization } \\
\end{array}$ & Occurrence & $\begin{array}{c}\text { Stage } \\
\text { of naturalization } \\
\end{array}$ \\
\hline Fabaceae & Robinia hispida L. & tree & seed, vegetative way & colonophyte & local & establishing \\
\hline Fabaceae & R. neomexicana A. Gray & tree & seed, vegetative way & colonophyte & local & establishing \\
\hline Fabaceae & R. viscosa Vent. & tree & seed, vegetative way & colonophyte & local & establishing \\
\hline Fabaceae & Sophora japonica L. & tree & seed & colonophyte $_{\mathrm{c}}$ & unique & survival \\
\hline Fabaceae & Spartium junceum L. & shrub & seed, vegetative way & colonophyte $_{\mathrm{c}}$ & sporadic & establishing \\
\hline Rosaceae & Amelanchier ovalis Medik. & tree/shrub & seed & ephemerophyte & local & establishing \\
\hline Rosaceae & Aronia melanocarpa (Michx.) Elliott & tree & seed & ephemerophyte & local & establishing \\
\hline Rosaceae & $\begin{array}{l}\text { Cerasus tomentosa (Thunb.) Wall. } \\
\text { ex T.T. Yu \& C.L. Li }\end{array}$ & shrub & seed & ephemerophyte & rare & reproduction \\
\hline Rosaceae & $\begin{array}{l}\text { Chaenomeles japonica (Thunb.) Lindl. } \\
\text { ex Spach }\end{array}$ & shrub & seed, vegetative way & ephemerophyte & rare & reproduction \\
\hline Rosaceae & Cotoneaster glaucophyllus Franch. & shrub & seed & colonophyte $_{\mathrm{c}}$ & rare & reproduction \\
\hline Rosaceae & C. lucidus Schlecht. & shrub & seed & ephemerophyte & local & reproduction \\
\hline Rosaceae & C. melanocarpus Fisch. ex A. Blytt & shrub & seed & ephemerophyte & local & reproduction \\
\hline Rosaceae & Crataegus coccinea $\mathrm{L}$. & shrub & seed & ephemerophyte & rare & reproduction \\
\hline Rosaceae & C. sanguineus Pall. & shrub & seed & ephemerophyte & rare & reproduction \\
\hline Rosaceae & C. submollis Sarg. & shrub & seed & ephemerophyte & rare & reproduction \\
\hline Rosaceae & Malus baccata (L.) Borkh. & tree & seed & ephemerophyte & rare & reproduction \\
\hline Rosaceae & Mespilus germanica $\mathrm{L}$. & shrub & seed, vegetative way & ephemerophyte & rare & reproduction \\
\hline Rosaceae & Persica vulgaris Mill. & tree & seed & ephemerophyte & rare & reproduction \\
\hline Rosaceae & Prunus laurocerasus L. & shrub & seed, vegetative way & colonophyte $_{c}$ & local & establishing \\
\hline Rosaceae & P. mahaleb L. & shrub & seed & ephemerophyte & rare & reproduction \\
\hline Rosaceae & P. padus L. & tree/shrub & seed & ephemerophyte & rare & reproduction \\
\hline Rosaceae & P. vulgaris Schur & tree/shrub & seed, vegetative way & colonophyte $_{c}$ & sporadic & establishing \\
\hline Rosaceae & $\begin{array}{l}\text { Pyracantha rogersiana (A. B. Jacks.) } \\
\text { Coltm.-Rog. }\end{array}$ & shrub & seed, vegetative way & colonophyte $_{\mathrm{c}}$ & rare & reproduction \\
\hline Rosaceae & Rubus macrophyllus Weihe \& Nees & shrub & seed, vegetative way & ephemerophyte & unique & records \\
\hline Rosaceae & R. odoratus L. & shrub & seed, vegetative way & ephemerophyte & controlled & survival \\
\hline Rosaceae & Spiraea $\times$ billardii Hérin & shrub & seed, vegetative way & ephemerophyte & rare & survival \\
\hline Rosaceae & S. chamaedryfolia $\mathrm{L}$. & shrub & seed,vegetative way & ephemerophyte & rare & survival \\
\hline Rosaceae & S. douglasii Hook. & shrub & seed, vegetative way & ephemerophyte & rare & survival \\
\hline Rosaceae & S. salicifolia $\mathrm{L}$. & shrub & seed, vegetative way & colonophyte & rare & survival \\
\hline Rosaceae & S. $\times$ vanhouttei (Briot) Zabel & shrub & seed, vegetative way & ephemerophyte & rare & survival \\
\hline Ulmaceae & Celtis australis L. & tree & seed & colonophyte $_{\mathrm{c}}$ & rare & survival \\
\hline Ulmaceae & C. caucasica Willd. & tree/shrub & seed & colonophyte $_{\mathrm{c}}$ & rare & survival \\
\hline Ulmaceae & C. occidentalis L. & tree & seed & ephemerophyte & rare & survival \\
\hline Ulmaceae & Zelkova carpinifolia (Pall.) K. Koch & tree & seed & colonophyte $_{c}$ & rare & survival \\
\hline Moraceae & Maclura pomifera (Raf.) C. K. Schneid. & tree & seed, vegetative way & colonophyte $_{\mathrm{c}}$ & rare & survival \\
\hline Moraceae & Morus nigra $\mathrm{L}$. & tree & seed & colonophyte $_{\mathrm{c}}$ & sporadic & establishing \\
\hline Moraceae & M. rubra L. & tree & seed & colonophyte $_{c}$ & sporadic & establishing \\
\hline Fagaceae & Castanea sativa Mill. & tree & seed & colonophyte $_{\mathrm{c}}$ & unique & establishing \\
\hline Fagaceae & $\begin{array}{l}\text { Quercus macranthera Fisch. \& C. A. Mey. } \\
\text { ex Hohen. }\end{array}$ & tree & seed & ephemerophyte & controlled & establishing \\
\hline Fagaceae & Q.palustris Moench & tree & seed & ephemerophyte & rare & reproduction \\
\hline Juglandaceae & Juglans ailanthifolia Carrière & tree & seed & ergasiophyte & local & establishing \\
\hline Juglandaceae & J. cinerea $\mathrm{L}$. & tree & seed & ergasiophyte & local & establishing \\
\hline Juglandaceae & J. mandshurica Maxim. & tree & seed & ergasiophyte & local & establishing \\
\hline Juglandaceae & J. nigra L. & tree & seed & ergasiophyte & local & establishing \\
\hline Juglandaceae & J. regia $\mathrm{L}$. & tree & seed & ergasiophyte & sporadic & establishing \\
\hline Juglandaceae & J. subcordiformis Dode & tree & seed & ergasiophyte & local & establishing \\
\hline Celastraceae & Celastrus angulata Maxim. & liana & seed, vegetative way & colonophyte & local & survival \\
\hline Celastraceae & C. flagellaris Rupr. & liana & seed & ephemerophyte & local & survival \\
\hline Celastraceae & C. orbiculatus Thunb. & liana & seed & ephemerophyte & local & survival \\
\hline Anacardiaceae & Rhus glabra L. & tree/shrub & seed, vegetative way & colonophyte & rare & survival \\
\hline Anacardiaceae & R. typhina $\mathrm{L}$. & tree & vegetative way & colonophyte & controlled & survival \\
\hline Anacardiaceae & R. typhina L. 'Laciniata' & tree & vegetative way & colonophyte & controlled & survival \\
\hline Anacardiaceae & Toxicodendron pubescens Mill. & shrub & seed, vegetative way & ephemerophyte & rare & survival \\
\hline Aceraceae & $\begin{array}{l}\text { Acer platanoides L. f. atropurpurea } \\
\text { 'Krimson King' }\end{array}$ & tree & seed & ephemerophyte & controlled & survival \\
\hline Aceraceae & A. saccharinum $\mathrm{L}$. & tree & seed & colonophyte & sporadic & survival \\
\hline Hippocastanaceae & Aesculus flava Sol. & tree & seed & ephemerophyte & unique & records \\
\hline Hippocastanaceae & A. hippocastanum $\mathrm{L}$. & tree & seed & ergasiophyte & rare & esablishing \\
\hline Sapindaceae & Koelreuteria paniculata Laxm. & tree & seed & colonophyte $_{\mathrm{c}}$ & rare & survival \\
\hline Rutaceae & Phellodendron amurense Rupr. & tree & seed & ephemerophyte & unique & records \\
\hline Tiliaceae & Tilia begoniifolia Steven & tree & seed, vegetative way & ephemerophyte & rare & survival \\
\hline Cistaceae & Poncirus trifoliata (L.) Raf. & tree/shrub & seed & ephemerophyte & rare & reproduction \\
\hline Hydrangeaceae & Deutzia scabra Thunb. & shrub & seed, vegetative way & ephemerophyte & rare & survival \\
\hline Hydrangeaceae & Philadelphus microphyllus A. Gray & shrub & seed, vegetative way & ephemerophyte & rare & reproduction \\
\hline Ebenaceae & Diospyros lotus L. & tree & seed, vegetative way & colonophyte $_{c}$ & rare & survival \\
\hline Eucommiaceae & Eucommia ulmoides Oliver. & tree & seed, vegetative way & ephemerophyte & unique & records \\
\hline Oleaceae & Olea europaea L. & tree & seed, vegetative way & colonophyte & rare & establishing \\
\hline Scrophulariaceae & Buddleja davidi Franch. & shrub & seed, vegetative way & colonophyte $_{\mathrm{c}}$ & unique & records \\
\hline Paulowniaceae & Paulownia tomentosa (Thunb.) Steud. & tree & seed & ephemerophyte & unique & records \\
\hline Bignoniaceae & Catalpa bignonioides Walter & tree & seed, vegetative way & $\begin{array}{l}\text { colonophyte }_{\mathrm{c}} \\
\text { ephemerophyte }\end{array}$ & unique & survival \\
\hline Bignoniaceae & Campsis grandiflora (Thunb.) K. Schum. & liana & vegetative way & colonophyte & controlled & establishing \\
\hline
\end{tabular}




\begin{tabular}{|c|c|c|c|c|c|c|}
\hline Family & Taxon & Life-form & Spread & $\begin{array}{c}\text { Degree } \\
\text { of naturalization }\end{array}$ & Occurrence & $\begin{array}{c}\text { Stage } \\
\text { of naturalization }\end{array}$ \\
\hline Bignoniaceae & C. radicans (L.) Seem. & liana & vegetative way & colonophyte & controlled & establishing \\
\hline Aquifoliaceae & Ilex aquifolium $\mathrm{L}$. & tree & seed, vegetative way & ephemerophyte & unique & records \\
\hline Caprifoliaceae & Lonicera caerulea L. & shrub & seed & ephemerophyte & rare & survival \\
\hline Caprifoliaceae & L. caprifolium $\mathrm{L}$. & shrub & seed & colonophyte $_{c}$ & rare & survival \\
\hline Caprifoliaceae & L. standishii Jacques & shrub & seed & colonophyte $_{c}$ & rare & survival \\
\hline Caprifoliaceae & Weigela florida (Bunge) A. DC. & shrub & seed, vegetative way & ephemerophyte & rare & survival \\
\hline Aracaceae & Aralia elata (Miq.) Seem. & shrub & seed, vegetative way & ephemerophyte & controlled & survival \\
\hline
\end{tabular}

A general overview of the course of invasion of woody species into the spontaneous flora of Ukraine

According to the results of our determination and analysis of the group of non-native woody species, this component of the spontaneous flora of Ukraine has a rather diverse taxonomy: 182 species, belonging to 95 genera and 45 families. These include 71 alien species, which have completely naturalized. Let us compare: the global database of invasive trees and shrubs contains 751 alien species (434 trees and 317 shrubs); the flora of Europe has 134 of them (Rejmánek \& Richardson, 2013). It is evident that it has no significant relevance for the course of invasion whether the life-form is a tree or a shrub. The involvement of trees in the total list slightly exceeds the involvement of shrubs, and as for alien species - they are even (Table 7). The most intense distribution has been noted mainly for the species remarkable both for seed dispersal and vegetative reproduction, though most non-naturalized species have only seed dispersal. Mostly common and rare species are noted in the total list in terms of occurrence and distribution, which is explained by high involvement of these very species among alien and non-naturalized ones.

The course of invasion of non-native woody species, which are at the initial stages of migration - introduction, acclimatization, survival, adaptation of reproductive sphere and establishment (Blackburn et al., 2011) - and have not naturalized yet, takes place after overcoming the geographical barrier as a result of human activity. Continuing their introduction, they cross the barriers of controlled cultivation, a barrier to survival and adaptation of reproductive sphere, and start the formation and establishment of populations. According to our observations, only 30 of them have established local populations, have cryptic (hidden) invasion risk, and the rest of the non-naturalized species do not manifest any invasive activity. First of all, noteworthy are vegetatively mobile shrubs of Rhus typhina, R. typhina 'Laciniata', Rubus odoratus and lianas Ampelopsis aconitifolia, A. delavayana var. glabra, A. bodinieri, A. glandulosa var. brevipedunculata, Campsis grandiflora, C. radicans, Clematis gouriana, C. jackmanii, C. ligusticifolia, C. tangutica, C. viticella and Vitis coignetiae. The global pattern of plant invasions demonstrates that under favourable conditions the species of these life-forms invade a territory fast and retain there hold on it. The studies on the naturalization in forests and parks of Kyiv demonstrated that 6 species of the genus Juglans (J. ailanthifolia, J. cinerea, J. mandshurica, J. nigra, J. regia, J. subcordiformis) (Burda \& Koniakin, 2018) and Aesculus hippocastanum establish self-reproductive local populations. As for further successful or failing seed dispersal of trees (Acer platanoides $\mathrm{f}$. atropurpurea 'Krimson King', Celtis australis, Larix decidua, Quercus macranthera), it is too early to forecast anything. The mentioned ornamental form of Acer platanoides is present in some parks of Kyiv, but there were no reports about self-dispersal. Non-naturalized and not high trees or shrubs (Aralia elata, Parrotia subaequalis, Thuja occidentalis) are still undergoing the processes of acclimatization and adaptation of reproductive sphere. Such shrubs as Berberis thunberii and Ribes americanum do not have abundant seed dispersal. Thus, the group of nonnative woody species combines the species with hidden or non-expressed invasive activity. At first sight, they are completely undynamic, almost invisible in flora, plant communities, ecosystems and landscape. However, at the impact of some factors, for instance, factors of time, favourable conditions of reproduction, sharp change in environment, etc., their activity may be revealed. Most species, which have not naturalized, have not acquired sufficient vegetative development for at least some invasive activity, so they remain passive in terms of this feature for some time.
The picture of invasive activity of alien species is quite different. The species, which have formed secondary ranges within Ukraine, are known as invasively active species, at least within Europe and Northern 289 . Transformer species in the spontaneous flora of Ukraine are revealed as the most wide spread in almost 40 regions of Europe: Robinia pseudoacacia (42 regions), Ailanthus altissima (40), Acer negundo (38) (Lambdon et al., 2008). Some of our non-native plant species are among the more than "100 worst" alien species in Europe (Nentwig et al., 2018). There are Pueraria lobata var. montana (rank 10 and total impact sum 29), Robinia pseudoacacia (13 and 28), Prunus serotina (59 and 17), Elaeagnus angustifolia (67 and 16), Rosa rugosa (76 and 13) and Buddleja davidii (80 and 11 respectively).

Table 7

The diversity of non-native woody species in spontaneous flora of Ukraine

\begin{tabular}{|c|c|c|c|}
\hline \multirow{2}{*}{ Feature } & \multicolumn{3}{|c|}{ Number of species } \\
\hline & total & alien & on-naturalized \\
\hline \multicolumn{4}{|c|}{ Taxonomic diversity } \\
\hline of species & 182 & 71 & 111 \\
\hline of genera & 95 & 47 & 65 \\
\hline of families & 45 & 28 & 35 \\
\hline \multicolumn{4}{|c|}{ Life-form } \\
\hline tree & 75 & 30 & 45 \\
\hline shrub & 64 & 26 & 38 \\
\hline tree or shrub & 16 & 7 & 9 \\
\hline liana & 27 & 8 & 19 \\
\hline \multicolumn{4}{|c|}{ Spreading } \\
\hline seed dispersal & 77 & 15 & 62 \\
\hline vegetative way & 4 & 0 & 4 \\
\hline both way & 101 & 56 & 45 \\
\hline \multicolumn{4}{|c|}{ Occurrence } \\
\hline common species & 44 & 44 & 0 \\
\hline local species & 34 & 17 & 17 \\
\hline sporadic species & 11 & 4 & 7 \\
\hline rare species & 57 & 6 & 51 \\
\hline unique species & 13 & 0 & 13 \\
\hline controlled species & 23 & 0 & 23 \\
\hline \multicolumn{4}{|c|}{ *Degree of naturalization } \\
\hline agriophyte & 35 & 35 & 0 \\
\hline hemiagriophyte & 5 & 5 & 0 \\
\hline epoecophyte & 16 & 16 & 0 \\
\hline ergasiophyte & 23 & 15 & 8 \\
\hline colonophyte & 42 & 0 & 42 \\
\hline ephemerophyte & 61 & 0 & 61 \\
\hline \multicolumn{4}{|c|}{ *Invasive activity } \\
\hline transformer species & 12 & 12 & 0 \\
\hline invasive species proper & 8 & 8 & 0 \\
\hline potentially invasive species & 29 & 29 & 0 \\
\hline $\begin{array}{l}\text { naturalized species with no manifested } \\
\text { invasive activity }\end{array}$ & 22 & 22 & 0 \\
\hline \multicolumn{4}{|c|}{ * Non-naturalized species, such stages of naturalization continue } \\
\hline introduction & 10 & 0 & 10 \\
\hline survival & 40 & 0 & 40 \\
\hline adaptation of reproduction sphere & 31 & 0 & 31 \\
\hline establishment & 30 & 0 & 30 \\
\hline
\end{tabular}

Note: * - the highest level has been accepted for species, which is quite different by the degree features at the local level.

The expansion of Amorpha fruticosa is observed in neighbouring countries. In the flood plain of Kuban near the town of Temriuk A. fruticosa formed compact clumps, pushing out native plant communities of hygro- and hydrophytes. There were cases when the traditional shrub life-form of $A$. fruticos $a$ was changed to the tree life-form. The height of trees was $6 \mathrm{~m}$ with the trunk diameter of $15 \mathrm{~cm}$ (Shvydkaya \& Kudinova, 2013). About two dozen alien woody species of the spontaneous 
flora of Ukraine have spread in 25 and more regions as the most common alien species of Europe: Prunus cerasus (34), Quercus rubra (34), Rosa rugosa (34), Prunus domestica (31), P. cerasifera (30), Aesculus hippocastanum (30), Pyrus communis (30), Syringa vulgaris (30), Malus domestica (29), Berberis aquifolia (28), Parthenocissus quinquefolia (27), Symphoricarpos albus (27), Juglans regia (26), Populus $\times$ canadensis (26), Vitis vinifera (26) (Lambdon et al., 2008).

Thus, coming back to the issue on the source of diaspores in the course of woody plant invasions in Ukraine, we would like to highlight a probable role of interstate migrations of invasive woody species. It is also possible that some migrations go both ways. At present, Ukraine's botanical gardens and arboretums have abundant and rather old collections. Some introduction centers own over 2,000 species of trees and shrubs. During their history (from 1793 till 2019), these institutions have passed on many woody exotic species for creation of forest cultures, use by communal services, to private amateurs, etc. In our country, woody species, used in gardening by the botanical gardens and arboretums after initial introductory testing, are planted to create current greenery of the cities along with the local species. They ensure comfortable life of local residents, promote optimization of microclimate in agriophyteoecosystems, protect railways and highways from unfavourable weather effects, resist water and wind erosion of soils, etc. In this situation, reports about immediate facts of woody species escaping the botanical gardens and arboretums which have introduced them, and establishing spontaneous plantings, are almost absent. We have managed to find only one abovementioned case of the "escape" of Clematis vitalba from the Donetsk Botanical Garden of NAS of Ukraine, on the mainland. This species is usually estimated by specialists as an unstable element of flora (colonophyte), remarkable for potential invasive activity, conditioned by the ability of both fast vegetative reproduction, and easy dispersal of seeds in the wind. As for the Crimean Peninsula, there is a registered fact of native penetration of Bupleurum fruticosum and Fraxinus ornus into the nature reserve "Mys Martian" from the adjacent territory of the Nikitsky Botanical Garden, where both species were naturalized long time ago (Bagrikova et al., 2014). However, the question about the nature of Fraxinus ornus in the Crimea is still under discussion. P. S. Pallas considered $F$. ornus on the South Coast of Crimea, in particular, in the plant communities on Mys Martian, to be an aboriginal East Mediterranean species, even 18 years prior to the establishment of the Nikitsky Botanical Garden. This thought coincides quite well with the opinions of some modern botanists. However, taking into consideration successful seed dispersal of $F$. ornus in modern plant community complexes, it seems reasonable to accept it as a transformer species on the South Coast of Crimea (Kish et al., 2009; Protopopova et al., 2012). The consequences of invasions of woody trees from the introduction centers seem to be negligible on the background of the events in domestic spontaneous flora. This conclusion is in agreement with the status of naturalization for woody plants from collections and expositions of the N. V. Tsytsyn Main Botanical Garden, RAS. Its specialists have not observed any fact of an introduced woody species escaping the garden in 70 years of introduction tests (Yatsenko \& Vinogradova, 2018). They have described the following course of migration: 2,400 species have been involved in the introduction experiment; 1,317 species (55\%) have overcome the ecological barrier and adjusted to new natural and climatic conditions; 66 species have overcome the reproductive barrier (5\%); 12 species have actually "left the arboretum" and invaded natural forest cenoses within the territory of the Garden (8\%). It should be noted that among 66 species, which have spread beyond the limits of cultivation, 10 species are aboriginal in the flora of Ukraine, and the rest are mostly mentioned in Tables 5 and 6.

Thus, the botanical gardens and arboretums of Ukraine as centers of plant introduction are neither direct sources of naturalization nor sources of spontaneous distribution of non-native woody species. The assumption about these institutions being the centers of initial introduction is surely reasonable.

In addition, the fact of seed dispersal, made by this or that species within the collection or under conditions, approximated to natural ones, is not a guarantee of its invasion in the nearest future. The way in which a plant migrates within a new territory is rather complicated, there may be "boom" and "bust" situations, or other occasions (Blackburn et al., 2011). There have been many situations when the invasion of some species started with seed dispersal and ended with it. For instance, Parrotia subaequalis was introduced into the arboretum of the M. M. Hryshko National Botanical Garden in 1950, the plants first blossomed in 1975 and the mature seeds had $98 \%$ germination. Abundant seed dispersal was observed the following year, however, the seedlings were soon eliminated. In the following years the plants of $P$. subaequalis blossomed, had seeds, but there was no seed dispersal (Doroshenko et al., 2013). In this respect, noteworthy are observations of the spreading of woody trees in the arboretum of the Donetsk Botanical Garden (Eremenko \& Ostapko, 2011). Three tendencies of distribution were noted under the controlled conditions of the arboretum during 10 years of observations. As expected, the species with the positive tendency include most invasive species: Acer negundo, Ailanthus altissima, Parthenocissus quinquefolia, potentially invasive: Morus alba, Ribes uvacrispa, and naturalized Gleditsia triacanthos, Berberis vulgaris and Juglans regia. The latter species sometimes establishes separate local self-reproducing populations in Donetsk on the background of abundant cultivation on private land. Decreasing dispersion was demonstrated by Berberis aquifolia, while Caragana arborescens, Ptelea trifoliata, Robinia pseudoacacia had a stable tempo of spreading.

In 55 years of observations, 227 alien woody species out of 73 genera and 31 families with seed dispersal were revealed in green plantings of Saint Petersburg. Among these, only about 10 species have become invasive and even threats to aboriginal plant communities (Firsov \& Byalt, 2015). For instance, these are species: Cornus saricea, Aronia mitschurinii A. Scvorts. et Maitull., Acer negundo, Amelanchier spicata.

262 species of vascular plants, which escaped the collections and expositions, were determined in the Tsytsyn Main Botanical Garden, RAS and the Botanical Garden of Lomonosov of the Moscow State University (Mayorov et al., 2013). Aralia elata and Symphoricarpus albus, capable of independent distribution in botanical gardens of Ukraine, are among them. Contrary to the abovementioned, in the arboretum of the Tsytsyn Main Botanical Garden, natural forest communities of the Garden were invaded from the outside greenery of the city by Acer negundo, Cotoneaster lucidus, Malus domestica (Yatsenko \& Vinogradova, 2018).

The phenomenon of naturalization of non-native species near collections and expositions of the botanical gardens and arboretums is of global character. Let us supplement the description of the experience of botanical gardens of Ukraine, Moscow and Saint Petersburg with the facts of Caragana arborescens, going out of cultivation within the Yakutsk Botanical Garden of the Institute of Biological Problems of Cryolithozone, the Siberian Division, RAS (on dry coastal shores of a lake, sometimes), which belongs to hemiagriophytes in Ukraine, and Sorbaria sorbifolia (in a birch forest, near collection plots), which is an epoecophyte in our flora (Nikolaeva \& Danilova, 2019).

Thus, important sources of naturalization of non-native woody species are green areas of cities, forest cultures, protective plantings of different intended purposes, private households, etc. The management of woody species invasion, the pragmatic unified framework for biological invasions (Blackburn et al., 2011), should be based on the global strategy on invasive alien species. The course of invasion of non-native woody species in the domestic flora dictates the following scheme of actions: preventing invasions, eradication - at the stages of survival and adaptation of the reproductive sphere, containment - after the species has overcome the barrier of reproduction and dispersal, and mitigation on the final stages of invasion.

\section{Conclusion}

This is the first and preliminary determination and evaluation of nonnative woody species in Ukraine's spontaneous flora. The data, presented in the article, demonstrate the active course of naturalization of nonnative woody species and invasion of alien species in the spontaneous flora. The tendencies towards global increase of involvement and invasive activity of alien woody species in the spontaneous domestic flora have been confirmed. 
The analysis of the occurrence, naturalization, distribution and the estimation of invasive activity of non-native species of trees, shrubs, and lianas in floras of 5 regions, 5 urban floras, over 30 floras of protected areas demonstrated as follows: there are 182 species from 95 genera and 45 families (75 trees, 16 trees or shrubs, 64 shrubs, and 27 lianas) are at different stages of naturalization in the spontaneous flora.

71 species have completely naturalized, 20 of which are invasive and pose the highest threat to local diversity (12 transformer species and 8 invasive proper ones). The rest of the naturalized species are potentially invasive ( 29 species) or do not demonstrate invasive activity ( 22 species).

111 species have overcome the geographical barrier due to human activity. These are undergoing the initial stages of invasion: survival, acclimatization, adaptation of reproductive sphere, establishment and formation of local populations.

In Ukraine, there are about 50 botanical gardens and arboretums centers of initial introduction of plants, 2 of them have been working since the end of the 18th century, and 8 - since the 19th century. The collections of 1 arboretum exceed 2,000, 2 botanical gardens have about 2,000 species, and the number of woody species in 4 botanical gardens and 1 arboretum exceeds 1,000 species. There is information about controlled spreading of 23 woody species beyond collections and expositions of the introduction centers. There was only one described case of spontaneous escape of 2 invasive woody species beyond the introduction center (Bupleurum fruticosum and Fraxinus ornus) from the Nikitsky Botanical Garden to the adjacent nature reserve "Mys Martian".

The mitigation of the effects of invasive alien woody species on local biodiversity requires restoration of local natural plant community complexes, organization of land use and culture of taking care of woody plantings. Our conclusions are relevant for employees of introduction centers, nature protection bodies, communal services, and state quarantine while elaborating the system of preventive, radical (eradication, limitation of assortment), containment and mitigation of impacts of plant invasions.

\section{References}

Abduloyeva, O. S., \& Karpenko, N. I. (2009). Traplyannya chuzhynnykh invaziynykh roslyn v syntaksonakh roslynnosti Ukrainy [The frequency of occurrence of alien invasive plants in syntaxons in Ukraine]. Chornomorski Botanical Journal, 5(1), 189-198 (in Ukrainian).

Alokhin, O. O., Orlova, T. G., \& Alokhina, N. M. (2019). Istoriya stvorennya ta suchasnyi stan kolektsii botanichnoho sadu Kharkivskoho natsionalnoho universytetu imeni V. N. Karazina [History and current state of the collection of the Botanical garden of the V. N. Karazin Kharkiv National University]. In: Alokhin, O. O. (ed.). Plant introduction: Current state, problems and prospects. The papers of International scientific conference and workshop (Kharkiv, May 17-19, 2019), Collegium, Kharkiv, 11-20 (in Ukrainian).

Bagrikova, N. A. (2013). Strukturnyi analiz adventivnoy fraktsii flory Krymskogo poluostrova (Ukraina) [Structural analysis of the alien fraction of the flora of the Crimean Peninsula (Ukraine)]. Ukrainian Botanical Journal, 70(4), 489507 (in Russian).

Bagrikova, N. A., \& Bondarenko, Z. D. (2015). Chuzherodnye rasteniya Yaltinskogo gorno-lesnogo prirodnogo zapovednika: Sostoyanie izuchennosti voprosa i perspektivy issledovaniya [Alien plants of Yalta Mountain Forest Nature Reserve: State of knowledge and prospects of research]. Russian Journal of Biological Invasions, 6(4), 2-13 (in Russian).

Bagrikova, N. A., Krainyuk, E. S., \& Resnikov, O. L. (2014). Osobennosti i perspektivy izucheniya adventivnyh vidov rasteniy zapovednika "Mys Martyan" [Features and prospects of studying adventive plants of the reserve "Mys Martian"]. In: Mayorov, S. R. (Ed.). Invasion biology: Current state and prospects: The workshop materials, Moscow, September 10-13, 2014. Maks Press, Moscow. Pp. 12-15 (in Russian).

Baranovski, B., Khromykh, N., Karmyzova, L., Ivanko, I., \& Lykholat, Y. (2016). Anyalysis of the alien flora of Dnipropetrovsk province. Biological Bulletin of Bogdan Chmelnitskiy Melitopol State Pedagogical University, 6(3), 419-429.

Blackburn, T. M., Essl, F., Evans, T., Hulme, P. E., Jeschke, J. M., Kühn, I., Kumschick, S., Markova, Z., Mrugała, A., Nentwig, W., Pergl, J., Pyšek, P., Rabitsch, W., Ricciardi, A., Richardson, D. M., Sendek, A., Vila, M., Wilson, J. R. U., Winter, M., Genovesi, P., \& Bacher, S. (2014). A unified classification of alien species based on the magnitude of their environmental impacts. PLoS Biology, 12(5), e1001850.

Blackburn, T. M., Pyšek, P., Bacher, S., Carlton, J. T., Duncan, R. P., Jarošik, V., Wilson, J. R. U., \& Richardson, D. M. (2011). A proposed unified framework for biological invasions. Trends in Ecology and Evolution, 26, 333-339.
Borsukevych, L. M., \& Prokopiv, A. I. (2014). Adventyvni vydy botanichnoho sadu Lvivskoho Natsionalnoho universytetu imeni Ivana Franka [Adventive species of the botanical garden of Ivan Franko National University of Lviv].

288 In: Glukhov, A. Z. (Ed.). Restoration of disturbed natural ecosystems: Materials of the V International scientific conference (Donetsk, May 12-15, 2014). Donetsk. Pp. 271-273 (in Ukrainian).

Burda, R. (1997). The checklist of Donbass's urban flora. Donetsk Botanical Garden, NAS of Ukraine, Donetsk.

Burda, R. (2003). Alien trees and shrubs of the Ukrainian agricultural landscape. In: Zajac, A., Zajac, M., \& Zemanek, B. (Eds.) Phytogeographical problems of synanthropic plants. Institute of Botany of Jagiellonian University, Cracow. Pp. 11-16.

Burda, R. (2007). Rezistentnist pryrodno-zapovidnoho fondu do fitoinvaziy [Resistance of natural-reserved fund to phytoinvasions]. Industrial Botany, 7, 1121 (in Ukrainian)

Burda, R. (2018). Alien plant species in the agricultural habitats of Ukraine: Diversity and risk assessment. Ekológia (Bratislava), 37(1), 24-31.

Burda, R. I. (2014). Spontanne poshyrennya Aristolochia macrophylla (Aristolochiaceae) u lisakh Koncha-Zaspy (Kyiv) [Spontaneous dispersion of Aristolochia macrophylla (Aristolochiaceae) in Koncha-Zaspa forests, Kyiv]. Ukrainian Botanical Journal, 71(5), 558-562 (in Ukrainian).

Burda, R. I., \& Koniakin, S. N. (2018). Spontaneous dispersion of species of the genus Juglans L. in the forests and parks of Kyiv. Russian Journal of Biological Invasions, 9(2), 95-107.

Burda, R. I., Golivets, M. A., \& Petrovych, O. Z. (2015a). Alien species in the flora of the nature reserve fund of the flatland part of Ukraine. Russian Journal of Biological Invasions, 6(1), 6-20

Burda, R. I., Mulenkova, O. G., \& Shpilyova, N. V. (1998). Spontanne poshyrennya introdukovanykh roslyn na terytorii Donetskoho Botanichnoho Sadu [Spontaneous dispersion of introduced plants on the territory of the Donetsk Botanical Garden]. The Donetsk Botanical Garden, Donetsk (in Ukrainian).

Burda, R. I., Pashkevych, N. A., Boiko, G. V., \& Fitsailo, T. V. (2015b). Chuzhoridni vydy okhoronnykh flor Lisostepu Ukrainy [Alien species of the protected floras of Forest-Steppe of Ukraine], Naukova Dumka, Kyiv (in Ukrainian).

Cherevchenko, T. M. (Ed.). (2011). Botanichni sady i dendroparky RBSD Ukrainy: Dovidnyk [Botanical gardens and arboretums of the CBGA of Ukraine: Handbook]. Council of Botanical Gardens and Arboretums of Ukraine, Kyiv (in Ukrainian)

Didukh, Y., Plyuta, P., Protopopova, V., Ermolenko, V., Korotchenko, I., Karkutsiev, G., \& Burda, R. (2000). Ekoflora Ukrainy [Ecoflora of Ukraine]. Iss. 1. Phytosociocenter, Kyiv (in Ukrainian).

Doroshenko, O. K., Trofimenko, N. M., \& Babitskyi, A. I. (2013). Parrotia persica v Natsionalnomu botanichnomu sadu [Parrotia persica in the National botanical garden]. In: Radchenko, V. G. (ed.). The role of botanical gardens and arboretums in maintaining and enriching of biological diversity in urban areas. Materials of the International Scientific Conference (Kyiv, May 28-31, 2013). Kyiv. Pp. 207-209 (in Ukrainian).

Doyko, N. M., Kalashnikova, L. V., \& Doroshenko, Y. V. (2014). Invaziyno aktyvni derevni introdutsenty v dendroparku "Oleksandriya" [Invasively active introduced woody plants in the "Alexandria" arboretum]. In: Glukhov, A. Z. (Ed.). Restoration of disturbed natural ecosystems: Materials of the V International scientific conference (Donetsk, May 12-15, 2014). Donetsk. Pp. 274-275 (in Ukrainian).

Eremenko, Y. A., \& Ostapko, V. M. (2011). Rasprostranenie adventivnyh drevesno-kustarnikovyh rasteniy na territorii Donetskogo Botanicheskogo Sada NAN Ukrainy [Distribution of adventive trees and shrubs in the territory of Donetsk Botanical Garden, NAS of Ukraine]. Industrial Botany, 11, 135140 (in Russian).

Eremenko, Y. A., \& Ostapko, V. M. (2014). Tendentsii k naturalizatsii nekotoryh drevesno-kustarnikovyh introdutsentov na territorii Donetskogo Botanicheskogo Sada NAN Ukrainy [Tendencies to naturalization of some introduced trees and shrubs on the territory of Donetsk Botanical Garden, NAS of Ukraine]. In: Glukhov, A. Z. (ed.). Restoration of disturbed natural ecosystems: Materials of the V International Scientific Conference (Donetsk, May 12-15, 2014). Donetsk. P. 276 (in Russian).

Filatova, S. O., Osadcha, L. P., \& Azarova, L. V. (2014). Introdutsenty botanichnoho sadu. Holonasinni [Introduced plants of the botanical garden. Gymnosperms]. Odesa I. I. Mechnikov National University, Odesa (in Ukrainian).

Firsov, G. A., \& Byalt, V. V. (2015). Obzor drevesnyh ekzotov, dayushchikh samosev v Sankt-Peterburge (Rossiya) [Review of woody exotic species producing a self-sowing in Saint-Petersburg (Russia)]. Russian Journal of Biological Invasions, 6(4), 129-152 (in Russian).

Galkin, S. I., Doyko, N. M., \& Boyko, N. S. (2017). Kolektsiynyi fond derevnykh roslyn arboretumu "Oleksandriya" [Collection fund of woody plants of the arboretum "Alexandria"]. Forestry and Gardening, 11 (in Ukrainian)

Gaskin, J. F. (2017). The role of hybridization in facilitating tree invasion. AoB Plants, 9, plw079. 
Grevtsova, A. T. (ed.). (2000). Katalog rasteniy Krivorozhskogo Botaniheskogo Sada [Catalogue of plants of the Kryvyi Rih Botanical Garden]. Phytosociocenter, Kyiv (in Russian).

Hirsch, H., Richardson, M. D., \& Le Roux, J. J. (2017). Introduction to the special issue: Tree invasion: Towards a better understanding of their complex evolutionary dynamics. AoB Plants, 9, plx014

Kish, R. Y., Andrik, Y. Y., \& Kagalo, O. O. (2009). Yasen bilotsvityi. Fraxinus ornus L. [Flowering ash. Fraxinus ornus L.]. In: Didukh, Y. P. (ed.). Red data book of Ukraine. Vegetable Kingdom. Globalconsulting, Kyiv. P. 526 (in Ukrainian).

Kokhno, M. A. (1994). Okhorona henofondu derevnykh introdutsentiv v Ukrain [The protection of the gene pool of woody introduced plants in Ukraine]. In: Burda, R. I. (ed.). Protection of the gene pool of plants in Ukraine. Abstracts of scientific conferences (Kryvyi Rih, May 1994). Donetsk. Pp. 145-146(in Ukrainian)

Kokhno, M. A. (ed.). (1997). Katalog rasteniy TsRBS imeni N. N. Gryshko [Catalogue of plants of N. N. Gryshko CRBG]. Naukova Dumka, Kyiv (in Russian).

Kolisnychenko, O. V., Yakubenko, B. E., Slyusar, S. I., Shabarova, S. I., Hontar, V. T., Yakobchuk, O. M., Bilenko, V. G., Shevchuk, N. V., Mayevskyi, K. V., Chichikova, M. A., \& Shulzhenko, G. P. (2011). Kataloh roslyn Botanichnoho Sadu NUBiP Ukrainy [Catalogue of plants of the Botanical Garden of the National University of Life and Environmental Sciences of Ukraine]. National University of Life and Environmental Sciences of Ukraine, Kyiv (in Ukrainian)

Kondratyuk, E. N. (Ed.). (1988). Katalog rasteniy Donetskogo Botanicheskogo Sada [Catalogue of plants of the Donetsk Botanical Garden]. Naukova Dumka, Kyiv (in Russian)

Kormilitsin, A. M., \& Golubeva, I. V. (1970). Katalog dendrologicheskih kollektsiy arboretuma Nikitskogo Botanicheskogo Sada [Catalogue of arboretum dendrological collections of the Nikitsky Botanical Garden]. Yalta (in Russian).

Kosenko, I. S. (ed.). (2000). Kataloh roslyn Dendrolohichnoho Parku "Sofiivka" [Catalogue of plants of the Arboretum "Sofiivka"]. Uman (in Ukrainian).

Kucherevsckyi, V. V., \& Shol, H. N. (2009). Konspekt urbanoflory Kryvoho Rohu [List of plants of the Kryvyi Rih urban flora]. Press House, Kryvyi Rih (in Ukrainian).

Kvasha, V. V., Semenova, O. O., \& Chuvikina, N. V. (2010). Zapovidni terytorii Ukrainy. Botanichni sady ta dendroparky [Protected areas of Ukraine. Botanical gardens and arboretums]. Maximus, Kyiv (in Ukrainian).

Lambdon, P. W., Pyšek, P., Basnou, C., Hejda, M., Arianoutsou, M., Essl, F., Jarošík, V., Pergasiophytel, J., Winter, M., Anastasiu, P., Andriopoulos, P. Bazos, I., Brundu, G., Celesti-Grapow, L., Chassot, P., Delipetrou, P., Josefsson, M., Kark, S., Klotz, S., Kokkoris, Y., Kühn, I., Marchante, H., Pergasiophytelová, I., Pino, J., Vila, M., Zikos, A., Roy, D., \& Hulme, P. E. (2008) Alien flora of Europe: Species diversity, temporal trends, geographical patterns and research needs. Preslia, 80, 101-149.

Lykholat, Y. V., Khromykh, N. A., Ivan'ko, I. A., Matyukha, V. L., Kravets, S. S. Didur, O. O., Alexeyeva, A. A., \& Shupranova, L. V. (2017). Assessment and prediction of the invasiveness of some alien plants under the climatic changes in the Steppe Dnieper. Biosystems Diversity, 25(1), 52-59.

Lykholat, Y. V., Khromykh, N. O., Pirko, Y. V., Alexeyeva, A. A., Pastukhova, N. L., \& Blume, Y. B. (2018a). Epicuticular wax composition of leaves of Tilia L. trees as a marker of adaptation to the climatic conditions of the Steppe Dnieper. Cytology and Genetics, 52(5), 323-330.

Lykholat, Y., Khromykh, N., Didur, O., Alexeyeva, A., Lykholat, T., \& Davydov, V. (2018b). Modeling the invasiveness of Ulmus pumila in urban ecosystems under climate change. Regulatory Mechanisms in Biosystems, 9(2), 161-166.

Mayorov, S. R., Vinogradova, Y. K., \& Bochkin, V. D. (2013). Illustrirovannyi katalog rasteniy, dichayushchih $\mathrm{v}$ botanicheskih sadah Moskvy [An illustrated catalogue of plants, escaping from cultivation in botanical gardens of Moscow, Russia]. N. V. Tsitsin Main Botanical Garden of Russian Academy of Sciences, Fiton XXI, Moscow (in Russian).

Medvedev, V. A., \& Ilyenko, O. O. (2018). Dendrolohichna kolektsiya dendroparku "Trostyanets" NAN Ukrainy [Dendrological collection of the arboretum "Trostyanets", NAS of Ukraine]. In: Boyko, N. S., \& Doyko, N. M. (Eds). The history of creation, species composition, long-term dynamics of protected diversity of flora in botanical gardens and arboretums: Traditions, modernity, prospects: Materials of the International Scientific Conference on the 230th anniversary of the arboretum "Alexandria", NAS of Ukraine, September 19-20, 2018. Bilotserkivdruk, Bila Tserkva. Pp. 278-284 (in Ukrainian).

Mosyakin, S. L. (2013). Rodyny i poryadky kvitkovykh roslyn flory Ukrainy: Pragmatychna klasyfikatsiya ta polozhennya u filohenetychnij systemi [Families and orders of Angiosperms of the flora of Ukraine: A pragmatic classification and placement in the phylogenetic system]. Ukrainian Botanical Journal, 70(3), 289-307 (in Ukrainian).

Mosyakin, S. L., \& Yavorska, O. G. (2002). The non-native flora of the Kyiv urban area, Ukraine: A checklist and brief analysis. Urban Habitats, 1(1).

Nentwig, W., Bacher, S., Kumschick, S., Pyšek, P., \& Vila, M. (2018). More than "100 worst" alien species in Europe. Biological Invasions, 20, 1611-1621.

Nikolaeva, O. A., \& Danilova, O. S. (2019). Konspekt flory sosudistyh rasteniy prirodnoy territorii Yakutskogo Botanicheskogo Sada [Conspectus of the flo- ra of vascular plants of natural areas of the Yakutsk Botanical Garden]. Phytodiversity of Eastern Europe, 13(1), 70-94 (in Russian).

Ostapko, V. M., Mulenkova, O. G., \& Boiko, G. V. (2013). Novi vidomosti pro spontanne poshyrennya roslyn z Donetskoho Botanichnoho Sadu [New data on the spontaneous escaping of plants from the Donetsk Botanical Garden]. In Radchenko, V. G. (ed.). The role of botanical gardens and arboretums in maintaining and enriching of biological diversity in urban areas. Materials of the International Scientific Conference (Kyiv, May 28-31, 2013). Kyiv. Pp. 122-123 (in Ukrainian).

Pashkevych, N., \& Burda, R. (2017). Spread of alien plant species in the habitats of the Ukrainian Forest-Steppe. Ekológia (Bratislava), 36(2), 121-129.

Plugatar, Y. V., Koba, V. P., Gerasimchuk, V. N., \& Papelbu, V. V. (2015). Dendrologicheskaya kollektsiya arboretuma Nikitskogo Botanicheskogo Sada - sostoyanie i perspektivy razvitiya [Dendrological collection of arboretum of Nikitsky Botanical Gardens: Current state and trend development]. Achievements of Science and Technology of Agriophyteiculture, 29(12), 50-54 (in Russian).

Pollegioni, P., Olimpieri, I., Woeste, K. E., De Simoni, G., Gras, M., Malvolti, M. E. (2013). Barriers to interspecific hybridization between Juglans nigra L. and J. regia L. species. Tree Genetics and Genomes, 9(1), 291-305.

Prokopiv, A. (2004). Botanichnyi sad Lvivskoho Natsionalnoho Universytetu imeni Ivana Franka - istoriya ta suchasnist [The botanical garden of Ivan Franko National University of Lviv - history and the present]. Visnyk of Lviv University, Biology, 36, 3-9 (in Ukrainian).

Protopopova, V. V., Fedoronchuk, M. M., Shevera, M. V., \& Shevchyk, V. L. (2014). Vydy-transformery Serednoho Prydniprovya [Transformer species of the Middle Dnipro Region]. Ukrainian Botanical Journal, 71(5), 560-569 (in Ukrainian)

Protopopova, V. V., Shevera, M. V., Bagrikova, N. O., \& Ryff, L. E. (2012). Vydytransformery u flori Pivdennoho Bereha Krymu [Transformer species in the flora of the South Coast of Crimea]. Ukrainian Botanical Journal, 69(1), 54 68 (in Ukrainian).

Protopopova, V. V., Shevera, M. V., Chomei, I. I., Budzsak, V. V., Tokaryuk, A. I \& Korzhan, K. V. (2010). Vydy-transformery u flori Bukovynskoho Peredcarpattya [Transformer species in the flora of the Bukovyna Cis-Carpathian Area] Ukrainian Botanical Journal, 67(6), 852-864 (in Ukrainian).

Protopopova, V. V., Shevera, M. V., Mosyakin, S. L., Solomakha, V. A., Solomakha, T. D., Vasilieva, T. V., \& Petryk, S. P. (2009). Vydy-transformery u flori Pivnichnoho Prychornomorya [Transformer species in the flora of the Northern Black Sea Region]. Ukrainian Botanical Journal, 66(6), 770-782 (in Ukrainian)

Protopopova, V. V., Shevera, M. V., Orlov, O. O., \& Panchenko, S. M. (2015). The transformer species of the Ukrainian Polissya. Biodiversity: Research and Conservation, 39, 7-18.

Protopopova, V., \& Shevera, M. (2002). A preliminary checklist of urban flora of Uzhgorod. Phytosociocenter, Kyiv.

Pyšek, P., Meyerson, L., Simberloff, D. (2017a). Introducing 'Alien Floras and Faunas', a new series in Biological Invasions. Biological Invasions, 20(6), 1375-1376.

Pyšek, P., Perg, J., Essl, F., Lenzner, B., Dawson, W., Kreft, H., Weigelt, P. Winter, M., Kartesz, J., Nishino M., Antonova, L. A., Barcelona, J. F., Cabezas, F. J., Cárdenas, D., Cardenas-Toro, J., Castano, N., Chacon, E., Chatelain, C. Dullinger, S., Ebel, A. L., Figueiredo, E., Fuente, N., Genovesi, P. Groom, Q. J., Henderson, L., Inderjit, Kupriyanov, A., Masciadri, S., Maurel, N., Meerman, J., Morozova, O., Moser, D., Nickrent, D., Nowak, P.M., Pagad, S., Patzelt, A., Pelser, P. B., Seebens, H., Shu, W., Thomas, J., Velayos, M., Weber, E., Wieringa, J. J., Baptiste, M. P. \& van Kleunen, M. (2017b). Naturalized alien flora of the world: Species diversity, taxonomic and phylogenetic patterns, geographic distribution and global hotspots of plant invasion. Preslia, 89, 203-274.

Rejmánek, M., \& Richardson, D. M. (2013). Trees and shrubs as invasive alien species - 2013 update of the global database. Diversity and Distribution, 19(8), 1093-1094.

Rubtsov, A. F., Havrylenko, N. O., Slepchenko, L. O., Petrenko, Z. A., \& Lytvynenko, Y. S. (2012). Kataloh roslyn Dendrolohichnoho Parku "AskaniyaNova" [Catalogue of the plants of the Dendrological Park "Askania Nova"]. Askaniya-Nova.

Rubtsov, L. I., \& Gordienko, I. I. (Eds.). (1971). Derevya i kustarniki. Golosemennye [Trees and shrubs. Gymnosperms]. Naukova Dumka, Kyiv (in Russian).

Shvydkaya N. V. \& Kudinova, A. F. (2013). Osobennosti adventivnoy dendroflory urbanizirovannyh territoriy Krasnodarskogo kraya. In: Features of adventive dendroflora of urbanized territories of the Krasnodar Region. Materials of the International Scientific Conference (Kyiv, May 28-31, 2013). Kyiv. Pp. 163-164 (in Russian).

Shynder, O. I. (2013). Botaniko-heohrafichna dilyanka "Kavkaz" - oseredok vydovoi riznomanitnosti kavkazkoi flory u m. Kyevi [Botanical and geographical area "Caucasus" - the center of the species diversity of the Caucasian flora in Kyiv]. In: Radchenko, V. G. (Ed.). The role of botanical garden and arboretums in maintaining and enriching of biological diversity in urban 
areas. Materials of the International Scientific Conference (Kyiv, May 28-31, 2013). Kyiv. Pp. 298-300 (in Ukrainian).

Slyusarenko, O. M., Osadcha, L. P., Azarova, L. V., Filatova, S. O., \& Chaban, K. V. (2017). Introdutsenty botanichnoho sadu. Pokrytonasinni [Introduced plants of the Botanical Garden. Angiospermae]. Odesa I. I. Mechnikov National University, Odesa (in Ukrainian).

Solomakha, V. A. (Ed.) (2007). Botanichnyi Sad imeni O. V. Fomina. Kataloh roslyn [O. V. Fomin Botanical Garden. Index Plantarum]. Phytosociocenter, Kyiv (in Ukrainian).

Stankov, S. S. (1924-1925). O nekotoryh harakternyh kulturnyh i odichavshyh rasteniyah Yuzhnogo Berega Kryma [On some characteristic cultivated and wild plants of the South Coast of Crimea]. Journal on Applied Botany and Breeding, 14(4), 275-324 (in Russian).

Tarasov, V. V., Donchenko, Y. V., \& Krasnorepoecophyteva, T. V. (1998). Adventivnaya flora Dnepropetrovskogo Botanicheskogo Sada, DGU [Adventive flora of Dnipropetrovsk Botanical Garden, DSU]. In: Glukhov, A. Z. (Ed.). Industrial botany: The state and prospects of development. Materials of the Third International Scientific Conference (Donetsk, September 3-5, 1998). Donetsk. Pp. 97-98 (in Russian).

Tyshchenko, O. V., Tyshchenko, V. M., \& Kucheryava, L. F. (2013). Znakhidka Celastrus scandens L. (Celastraceae) v zapovidnomu urochyshchi Rizanyi Yar (Cherkaska oblast) [A new record of Celastrus scandens L. (Celastraceae) at protected area Rizanyi Yar (Cherkasy Region)]. Ukrainian Botanical Journal, 70(5), 646-648 (in Ukrainian).

van Kleunen, M., Dawson, W., Essl, F., Pergl, J., Winter, M., Weber, E., Kreft, H., Weigelt, P., Kartesz, J., Nishino, M., Antonova, L. A., Barcelona, J. F., Cabezas,
F. J., Cardenas, D., Cardenas-Toro, J., Castano, N., Chacon, E., Chatelain, C., Ebel, A. L., Figueiredo, E., Fuentes, N., Groom, Q. J., Henderson, L., Inderjit, Kupriyanov, A., Masciadri, S., Meerman, J., Morozova, O., Moser, D., Nickrent, D. L., Patzelt, A., Pelser, P. B., Baptiste, M. P., Poopath, M., Schulze, M., Seebens, H., Shu, W. S., Thomas, J., Velayos, M., Wieringa, J. J., Pyšek, P. (2015). Global exchange and accumulation of non-native plants. Nature, 525, 100-103.

van Kleunen, M., Essl, F., Pergl, J., Brundu, G., Carboni, M., Dullinger, M., Early, R., González-Moreno, P., Groom, Q. J., \& Hulme, P. E. (2018). The changing role of ornamental horticulture in alien plant invasions. Biological Reviews, 93(3), 1421-1237.

Yatsenko, I. O., \& Vinogradova, Y. K. (2018). Invazionnaya aktivnost drevesnyh rasteniy v Glavnom Botanicheskom Sadu im. N. V. Tsytsyna Rossiyskoy Academii Nauk [Invasive activity of woody plants in the Tsytsyn Main Botanical Garden of RAS]. Russian Journal of Biological Invasions, 9(4), 117131 (in Russian).

Zavyalova, L. V. (2010). A checklist of the Chernihiv urban flora. Phytosociocenter, Kyiv.

Zenni, R. D., Dickie, I. A., Wingfield, M. J., Hirsch, H., Crous, C. J., Meyerson, L. A., Burgess, T. I., Zimmermann, T. G., Klock, M. M., Siemann, E., Erfmeier, A., Aragon, R., Montti, L., \& Le Roux, J. J. (2017). Evolutionary dynamics of tree invasions: Complementing the unified framework for biological invasions. AoB Plants, 9, plw085.

Zvyagintseva, K. O. (2015). An annotated checklist of the urban flora of Kharkiv. V. N. Karazin Kharkiv National University, Kharkiv. 